\title{
ENGINEERING SOILS MAP OF CLAY COUNTY, INDIANA
}

NOVEMBER 1973 - NUMBER 26

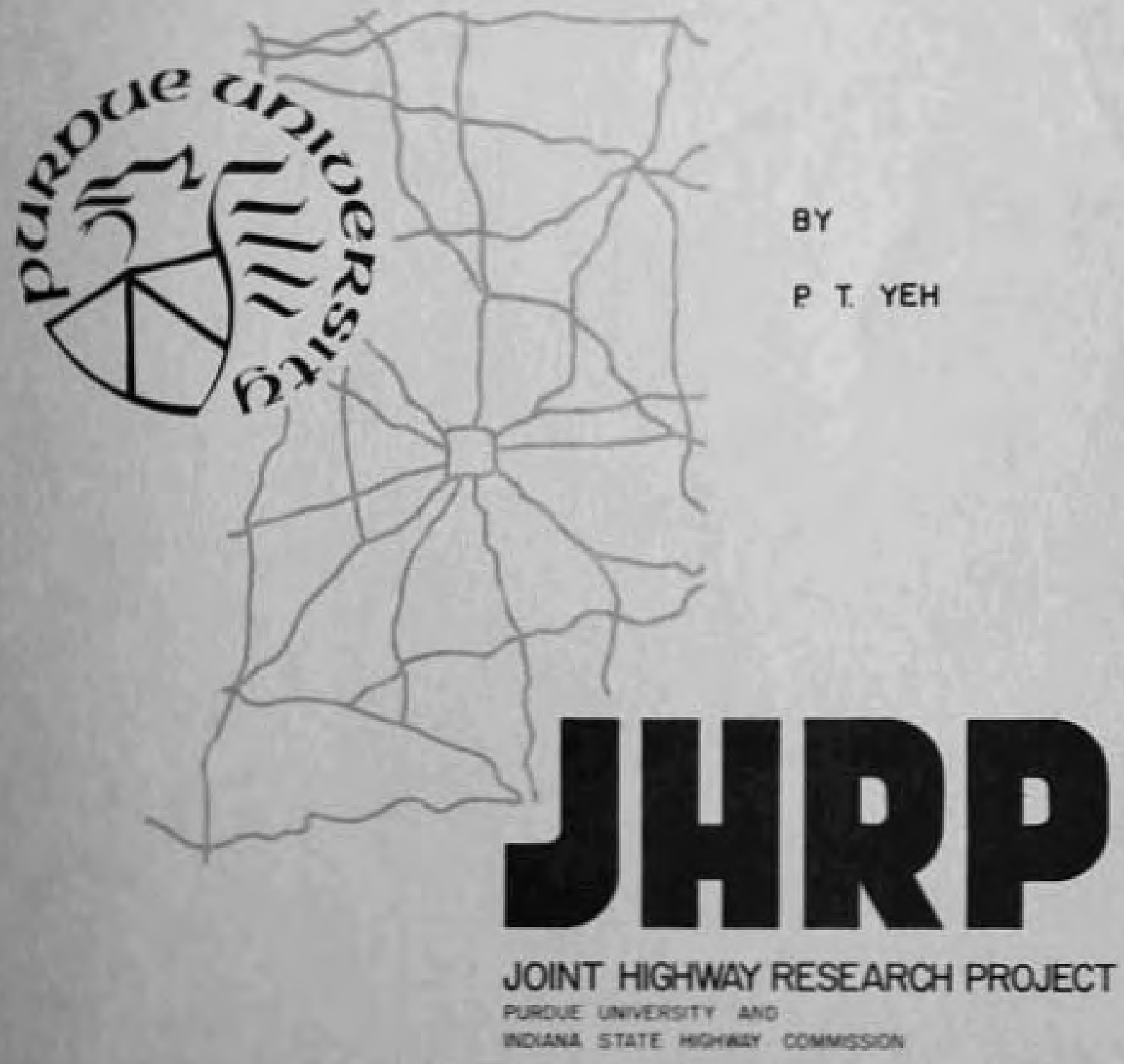


To: J. F. McLaughlin, Director Joint Highway Research Project

FROM: H. L. Michael, Associate Director Joint Highway Research Project
November 1, 1973

Project: C-36-51B

File: $1-5-2-54$

The attached report entitled "Fngineering Soils Map of C1ay County, Indiana", completes a portion of the project concerned with development of county engineering soils maps of the State of Indiana. This is the 54 th report in the series. The report was prepared by Dr. P. T. Yeh, Research Engineer, Joint Highway Research Project.

The soils mapping of Clay County was done primarily by airphoto interpretation. Some test data along $I-70$ are included in the report. Generalized soil profiles of the major soil for each land form are presented on the engineering soils map. An ozalid print of the enginnering soils map of Clay County is included in the report.

Respectively submitted,

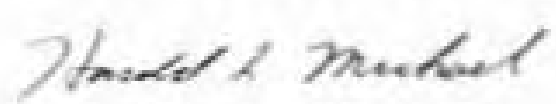

Harold L. Michael

Associate Director

III.M: $: \mathrm{w}$

$\begin{array}{lll}\text { cc: W. L. Dolch } & \text { R. H. Harrell } & \text { C. F. Scholer } \\ \text { R. L. Eskew } & \text { M. L. Ilayes } & \text { M. B. Scott } \\ \text { G. D. Gibson } & \text { C. W. Lovell } & \text { J. A. Spooner } \\ \text { W. H. Goetz } & \text { G. W. Marks } & \text { N. W. Steinkamp } \\ \text { M. J. Gutzwiller } & \text { R. D. Miles } & \text { H. R. J. Walsh } \\ \text { G. K. Hallock } & \text { G. T. Satterly } & \text { E. J. Yoder }\end{array}$




\section{Final Report}

ENGINEERING SOILS MAP OF CLAY COUNTY, INDIANA

Joint Highway Research Project

Project No.: C-36-51B

File No.: $\quad 1-5-2-54$

Conducted by

Joint Highway Rescarch Project

Engineering Experiment Station

Purdue University

In cooperation with

Indiana State Highway Commission

Purdue University

West Lafayette, Indiana

Novenber 1, 1973 


\section{AC.KNOWL.LDGMINTS}

The author wishes to acknoledge the assistance given by all those persons who have helped in the preparation of this report. Special acknowlegment are due the members of the advisory board Joint Highway Research Project for their active interest in furthering the study; Professor H. L. Nichae1, Asscciate Director, Joint Highway Research Project for review of the report; Professor R. D. Miles, in charge of the airphoto interpretation and photogrametry laboratory for review and valuable suggestions.

A11 airphoto used in connection with the preparation of this report autonatically carried the following credit lines: Photographed for Commodity Stabilization Service, performance and aerial photography division, United States Department of Agriculture. 
Digitized by the Internet Archive in 2011 with funding from

LYRASIS members and Sloan Foundation; Indiana Department of Transportation

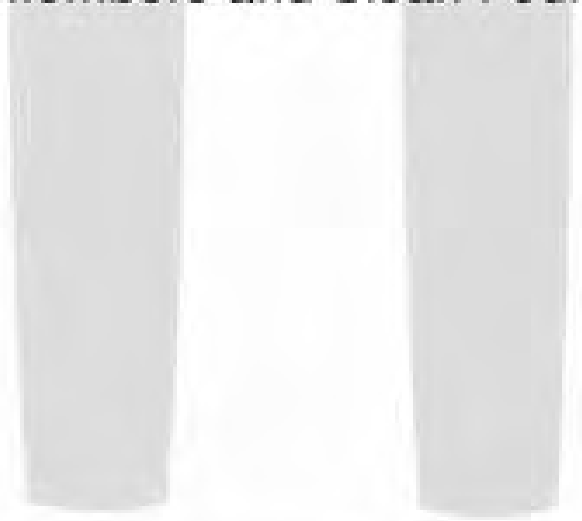

http://www.archive.org/details/engineeringsoils7326yehp 


\section{INTRODUCTION}

The engineering soils map of Clay County, Indiana which accompanies this report, was compiled from 7 in. $x 9$ in. aerial photographs having an approximate scale of $1: 20,000$. The aerial photographs were taken in July and August of 1939 for the United States Department of Agriculture and were purchased from that agency.

Aerial photographic interpretation of the land foras and engineering soils of this county was accomplished in accordance with accepted principles of observation and inference $(1)^{*}$. A two day field trip was made to the area for the purposes of resolving ambiguous details and correlating acrial photographic patterns with soil textures. Standard mapping symbols developed by the staff of the Airphoto Interpretation l.aboratory, School of Civil Engineering, Purdue University, were employed to delineate land forms and soil textures. The text of this report largely represents an effort to overcome the limitation imposed by adherence to a standard symbolism and map presentation.

A1 though no soil samples were collected and tested by the Joint llighway Research Project, general soil profiles were developed and are shown on the soils map. The soil profiles were conplicd fron the agriculture literature, information from adjacent counties and from the boring data of the roadway soil survey along I-70 supplied by the State llighway Commission. Liberal reference was made to "The Formation Distribution and Engineering Characteristics of 
Soils" (2), "Soil Survey of Clay County, Indiana" (3) and the lngineering Soils Map of Vigo and Owen Counties Indiana (4.5). DESCRIPTION OF AREA

General

Clay County is located in the southwest quarter of the State. The county is bounded on the north by Parke county, on the east by Putnam and Owen counties, on the south by Greene county and on the west by Sullivan and Vigo counties (Figure 1). C1ay county has a maximum length from north to south of 30 miles and a maximum width from east to west of 16 miles. The area of C1ay county is approximately 364 square miles or 232,960 acres (6).

Brazil situated in the northern part of the county is the county seat of government. The city is noted for the manufacture of clay products. A population of 23,933 inhibitants resided within the county at the time of the 1970 census of those 8,163 live in Brazil (7).

According to the 1964 Census of Agriculture 80.48 of C1ay county, or 187,310 acres, was farm 1 and (6). There were 31,428 acres of woodland in the county which was generally confined along the bluffs and gullies of the streams and rivers as shown in Figure 2. With the ever increasing strip mining activity the acreage of farmland and timber 1 and is being reduced accordingly.

Drainage Features

Clay County lies within two major drainage basins, namely: the Wabash River and the White River watersheds. The northwest corner and a small portion of the southwestern corner of the 


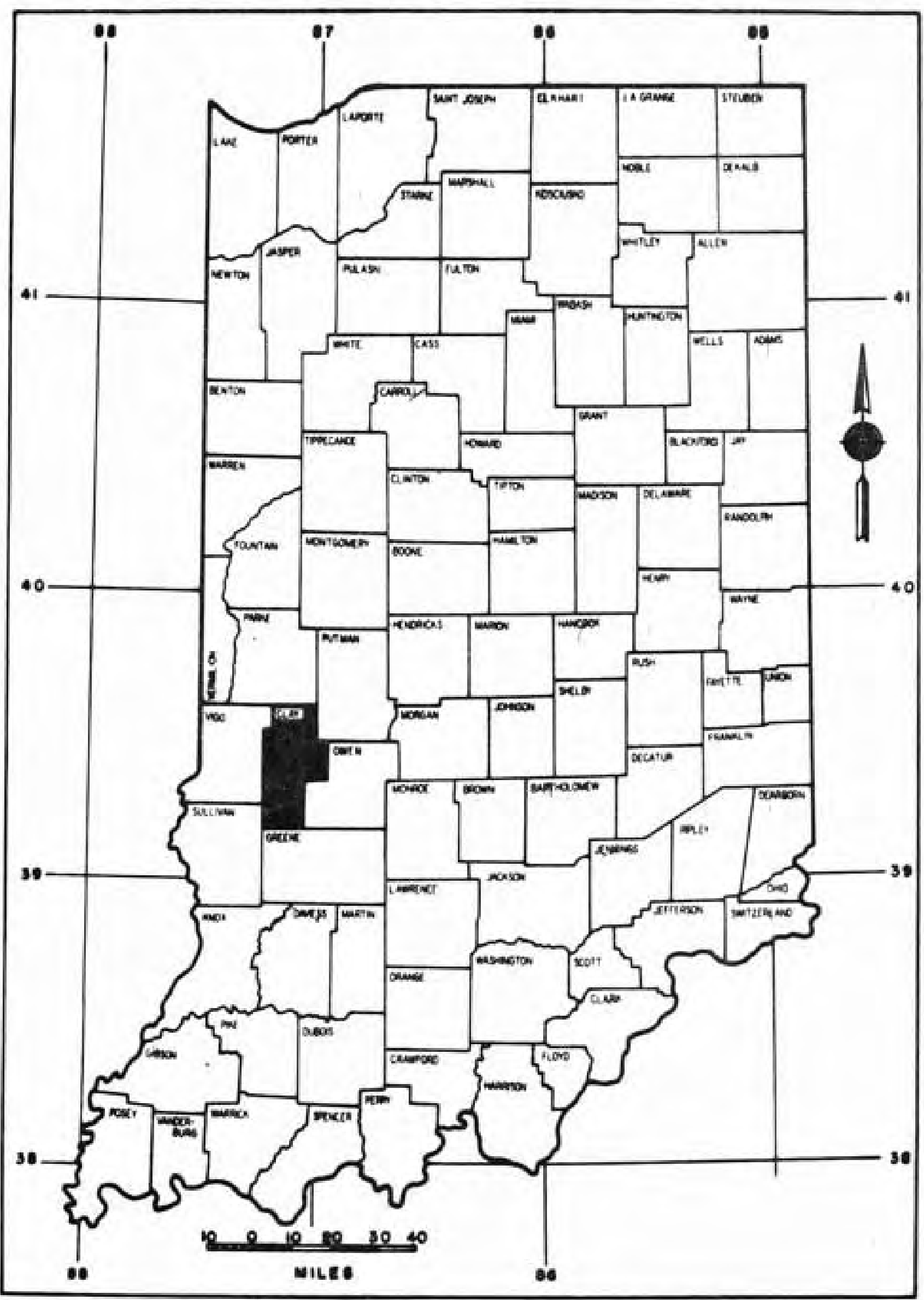

FIG. I LOCATION MAP OF CLAY COUNTY, INDIANA 


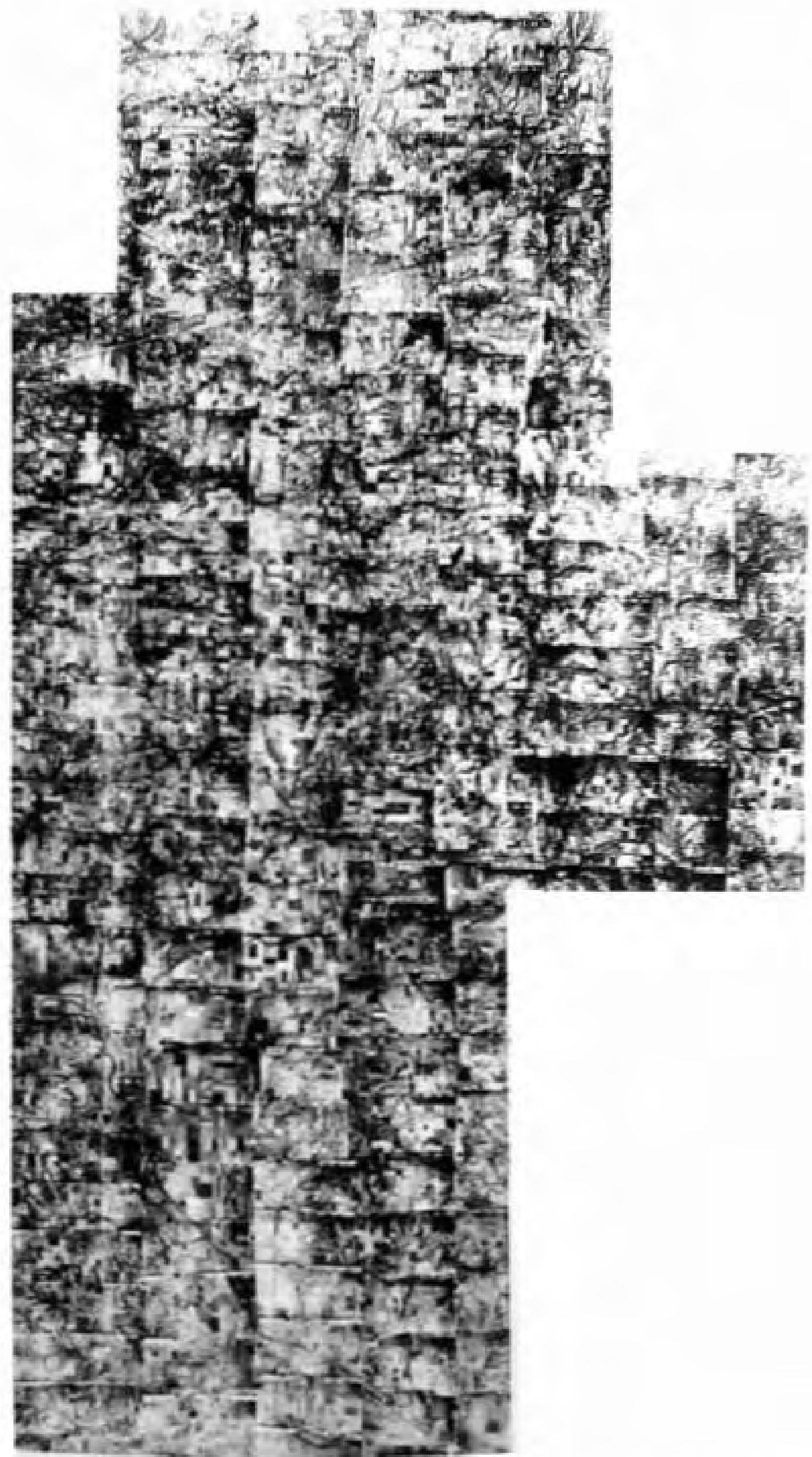

FIG.2. AIRPHOTO MOSAIC OF CLAY COUNTY, INDIANA 
county are in the Wabash River watershed and the remainder of the county is in the Eel River subdivision of the White River watershed (Figure 3). Most of the streams within the county flows in the southerly direction. However streams in the northwestern corner and in the eastern part have a westerly trend. The most outstanding feature of drainage in the county is the abrupt change in direction of Le1 River from a southwesterly to a southeasterly flowing stream. Tributaries in the southeastern part of the county have a tendency toward following the same curving course of Ee1 River particulary the Connelly Ditch.

The surface drainage is fairly well developed in the eastern part of the county. Most of the dissected uplands have a fine-textured drainage pattern. The courses of many natural drainage have been disrupted by strip mining operations.

Lel River has a wide flood plain. The river valley acted as a glacial sluiceway. ^ number of lacustrine and slack water terraces were formed along the river valley during the glacial period.

There are no natural lakes in the county. However, water-filled strip-mine pits and ponds of various origins exist in many sections of the county.

Ditches have been constructed in the Eel River bottoms, and streams have been dredged to improve drainage condition in the nearly level areas. Birch Creek and Connelly Ditch are the outstanding ones (see Figure 3) for extensively ditching. Rock control maybe observed on Six mile Creek. 


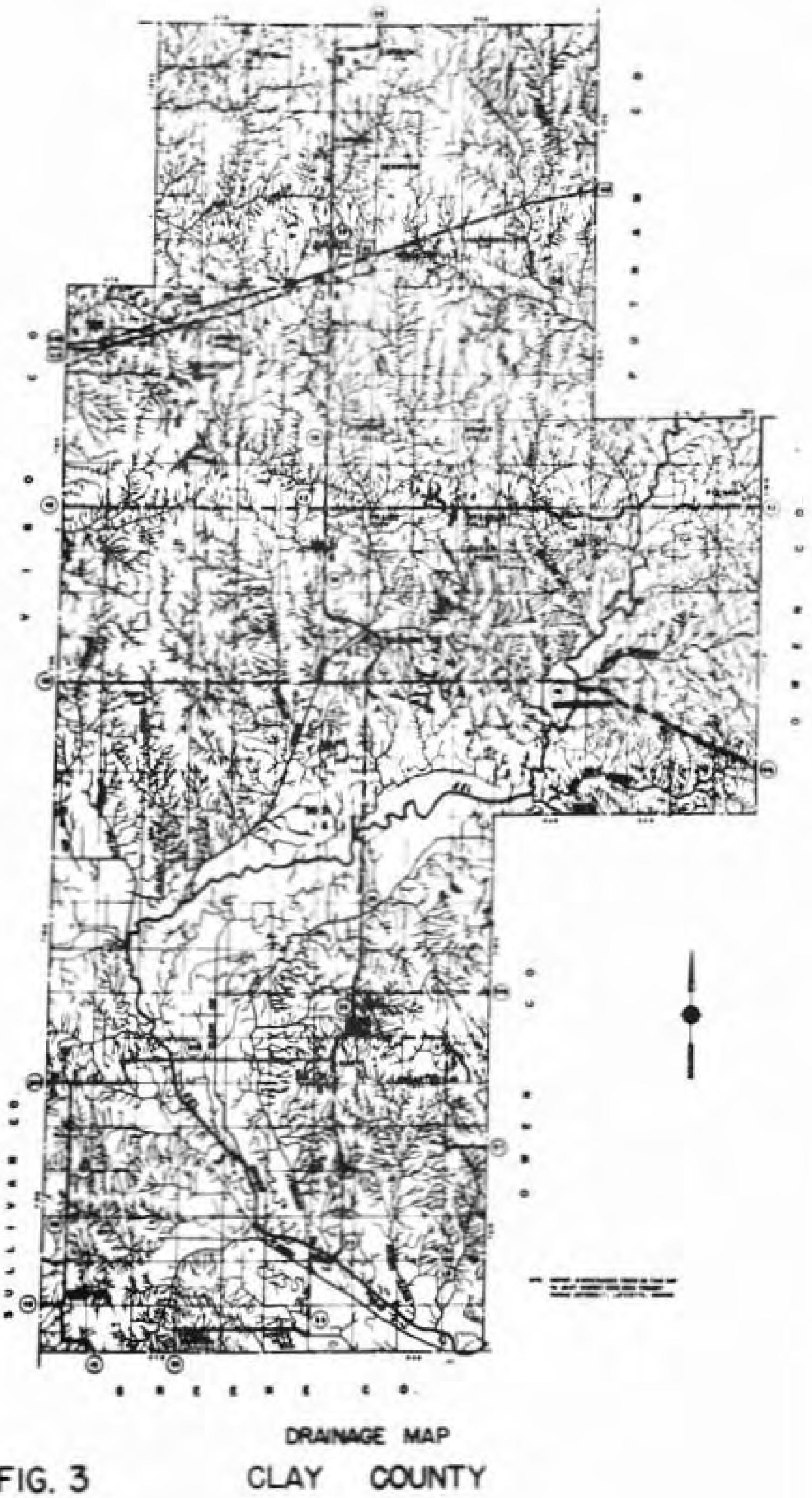


Climate

The climate of Clay County is continental, humid and temperate. There is no weather station within Clay County, but the records of the stations at Rockville, Parke County and at Farmersburg, Sullivan County, are fairly representative of the local climatic conditions. The annual precipitation taken from a 30-year mean (1934 to 1963) at Rockville is about 41 inches with an expected average snowfall of 23 inches (8). The average mean maximum and minimum temperature and precipitation collected from 1934 to 1963 , is 1 isted in Tab1e 1. The average and extreme temperature and precipitation at Farnersburg of Sullivan County (9) is listed on Table 2 .

Physiography

Clay County lies mainly in the Kabash Lowland province, except the extrene castern portion which belongs to the Crawford Upland province of the State (Figure 4). With respect to its physiographical situation in the United States, Clay County is a part of the Till Plain Section of the Central Low 1 and Province $(10)$.

\section{Topography}

Clay County as a whole is relatively flat especially the western half. The surface of the county is that of an llinoian glacial plain. The primary breaks in the flat surface are cause by the wide (as much as five miles), flat, flood plains of Eel River and its tributaries (see Figure 5). The generally flat glacial plain has also been dissected by numerous small streans, and gullies and by strip mines 
Table 2

AVERAGES AND EXTREMES OF THMPERATURE AND PRECIPITATION AT FARMERSBURG, SULLIVAN COUNTY, INDIANA

\begin{tabular}{|c|c|c|c|c|c|c|}
\hline \multirow[t]{2}{*}{ Month } & \multicolumn{3}{|c|}{ Temperature } & \multicolumn{3}{|c|}{ Precipitation } \\
\hline & $\begin{array}{l}\text { Average } \\
{ }^{\circ} \mathrm{F}\end{array}$ & $\begin{array}{l}\text { Absolute } \\
\text { Maximum } \\
{ }_{\mathrm{F}}\end{array}$ & $\begin{array}{l}\text { Absolute } \\
\text { Minimum } \\
{ }^{\circ} \mathrm{F}\end{array}$ & $\begin{array}{l}\text { Average } \\
\text { Inches }\end{array}$ & $\begin{array}{l}1 \text { in } 10 \mathrm{yr} . \\
\text { less then }\end{array}$ & $\begin{array}{l}1 \text { in } 10 \text { yrs. } \\
\text { more than }\end{array}$ \\
\hline January & 31 & 77 & -24 & 2.7 & 0.7 & 7.3 \\
\hline February & 33 & 75 & -23 & 1.9 & 0.5 & 3.6 \\
\hline March & 43 & 88 & -5 & 3.4 & 1.4 & 7.0 \\
\hline April & 53 & 88 & 21 & 3.3 & 1.7 & 6.3 \\
\hline May & 64 & 96 & 20 & 4.6 & 1.3 & 8.9 \\
\hline June & 72 & 104 & 38 & 4.0 & 1.6 & 7.5 \\
\hline July & 77 & 111 & 46 & 2.9 & 1.0 & 5.6 \\
\hline August & 75 & 106 & 41 & 3.4 & 1.0 & 6.4 \\
\hline Sept. & 69 & 105 & 21 & 3.7 & 1.0 & 6.3 \\
\hline October & 57 & 93 & 19 & 2.9 & 0.7 & 5.7 \\
\hline November & 44 & 90 & -4 & 2.6 & 1.1 & 4.6 \\
\hline December & 33 & 71 & -19 & 2.4 & 0.7 & 4.7 \\
\hline Year & 54 & 111 & -24 & 37.8 & 28.7 & 46.3 \\
\hline
\end{tabular}


Table 1

AVERAGE TEMPERATURE AND PRECIPITATION IN ROCKVILLE, PARKE COUNTY, INDIANA

\begin{tabular}{|l|c|c|c|c|}
\hline \multirow{2}{*}{ Month } & \multicolumn{3}{|c|}{ Temperature } & $\begin{array}{c}\text { Precipitation } \\
\text { in } \\
\text { inches }\end{array}$ \\
\cline { 2 - 5 } & Mean $\left({ }^{\circ} \mathrm{F}\right)$ & Average Max. $\left.{ }^{\circ} \mathrm{F}\right)$ & Average Min. $\left.{ }^{\circ} \mathrm{F}\right)$ & 2.76 \\
\hline January & 29.0 & 37.1 & 20.8 & 2.44 \\
March & 31.0 & 40.4 & 23.1 & 3.78 \\
Apri1 & 52.7 & 50.6 & 31.5 & 3.81 \\
May & 61.3 & 63.3 & 42.1 & 4.86 \\
June & 72.7 & 74.4 & 48.2 & 5.24 \\
July & 76.3 & 83.9 & 61.5 & 3.78 \\
Nugust & 74.8 & 87.7 & 64.8 & 3.32 \\
Sept. & 67.2 & 86.1 & 63.5 & 2.86 \\
October & 57.1 & 78.9 & 55.5 & 2.84 \\
November & 42.2 & 68.7 & 45.5 & 3.04 \\
December & 31.4 & 51.3 & 33.0 & 2.36 \\
Annual & 53.2 & 39.2 & 23.5 & 41.09 \\
\hline
\end{tabular}




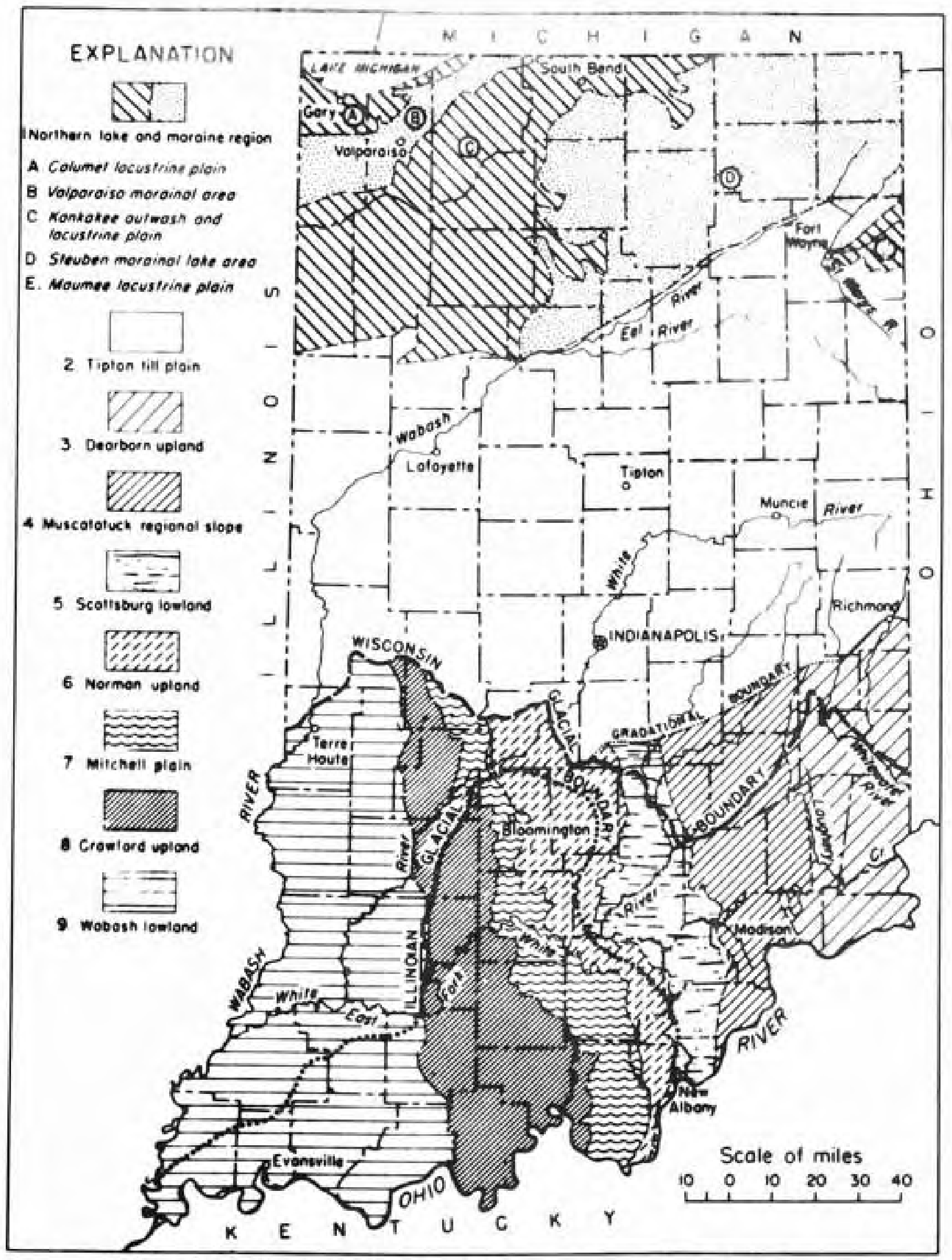

Figure 4 Mop of Indiano showing regional physiographic units bosed on present topography. Modified from Malott 


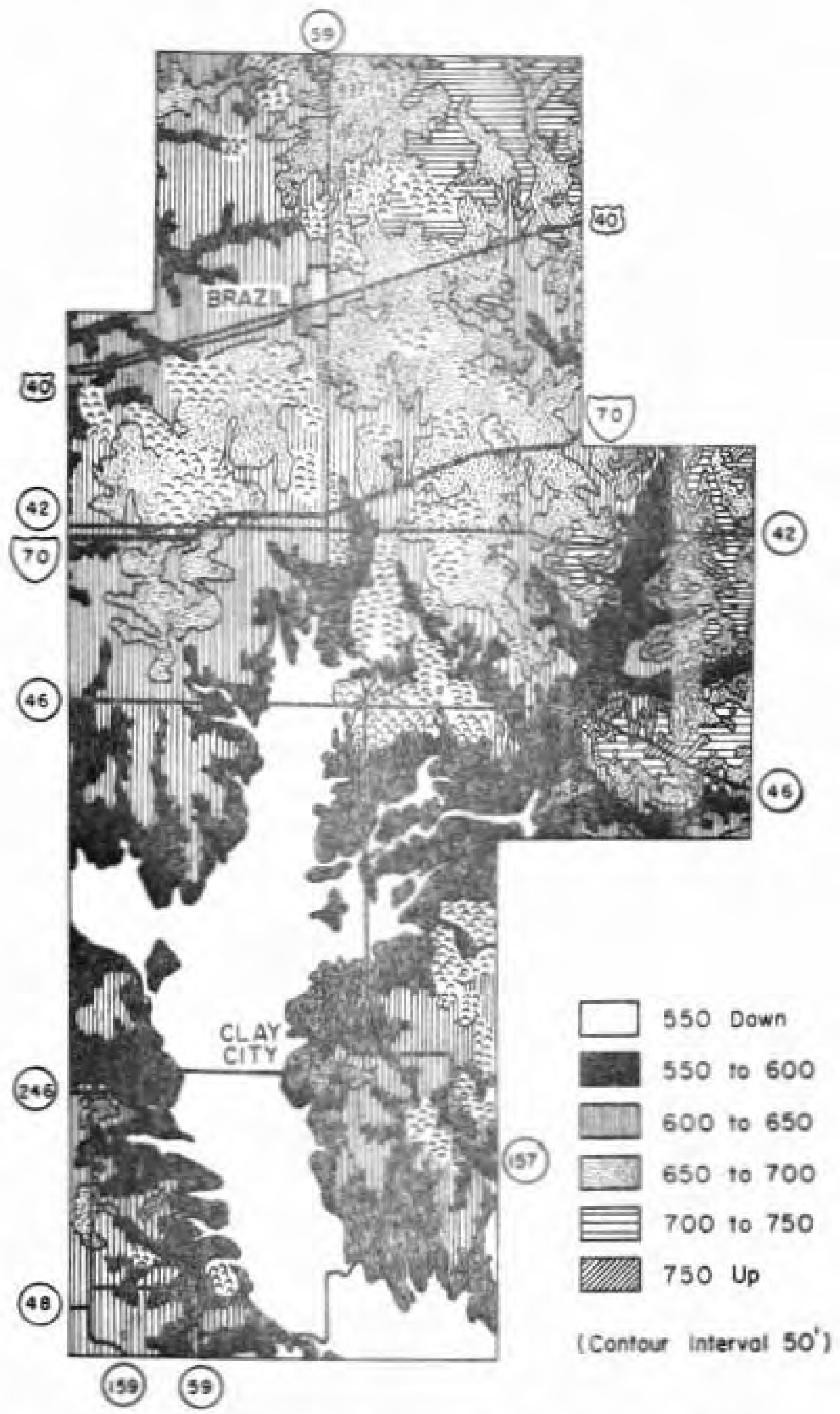

FIG. 5 TOPOGRAPHIC MAP OF CLAY COUNTY INDIANA 
activities. A belt of sand dunes and sandy plains has produced some low rolling hills on the east bank of the Eel River Valley.

The General elevation of the upland or the glacial drift plain ranges from 600 to 720 feet about sca level. The lacustrine plains and the slack water terraces in general varies from 540 to 580 feet in elevation. The highest elevation of the county is about 780 feet founded at two points at the northeastern corner of the county. One is near the border with Putnam and Owen Counties, the other with Parke and Putnam countics. The lowest elevation of Clay County is about 500 feet about sea level, located in the Fel River at the point where the river leaves the county at the southeastern corner. Maximum local relief of 145 feet occurs at a point about threc miles northeast of Bowling Green. Local relief, in the magnitude of 100 feet, is common along the bluff of Jordan Creek and Six Mile Creek. Strip waste piles, with intervening lakes and ponds and quarries add unique landscape features to the relatively level plain in Clay County.

$\underline{G \operatorname{colog} y}$

Nearly all areas of Clay County are covered by the unconsolidated glacial material of the Butlerville Till Member of the Jessup Formation (11). The uplands are primarily Illinoian glacial drift with a loess cover, an exception is the be1t of sand dunes and the sandy plain along the east bank of Eel River. Most of the lowlands consist of Wisconsinan Valley train and lacustrine deposits, classified as the 
Martinsville Formation and the Lacustrine facies of the Atherton Formation by Wayne (11).

The thickness of the 111 inoian drift varies from nothing to 40 feet or more (12). In the upland the drift is usually about 20 to 30 feet in depth (13). The drift is thinner along Six Mile Creek near the border with Owen County.

The bedrock strata beneath the glacial material in Clay County almost wholly belongs to the Pennsylvanian system. llowever, a small strip in the castern part is recognized as the Blue River Group of the lower Chester Series of the Mississippian system (see Figure 6). The Carbondale Group of the Allegheny series occupies the western part of the county, while the Raccoon Creek Group of the Pottsville series underlies the major portion of the county.

Numerous rock exposures occur along the major rivers and streams and rock is exposed in strip mine areas and quarries. Shale outcrops occur along North Forke of Otter Creck, branch of McIntyre's Creek, Hog Creek and in the vicinity of Centre Point (14). Sandstone outcrop are found along Eel River and its tributaries in the eastern third part of the county. The only limestone outcrop (about 10 feet in thickness, overlain by 30 feet of arenaceous shale) lies in the bank of Jorden Creek, about $11 / 4 \mathrm{miles}$ northeast of Bowling Green as reported by Cox (12). 


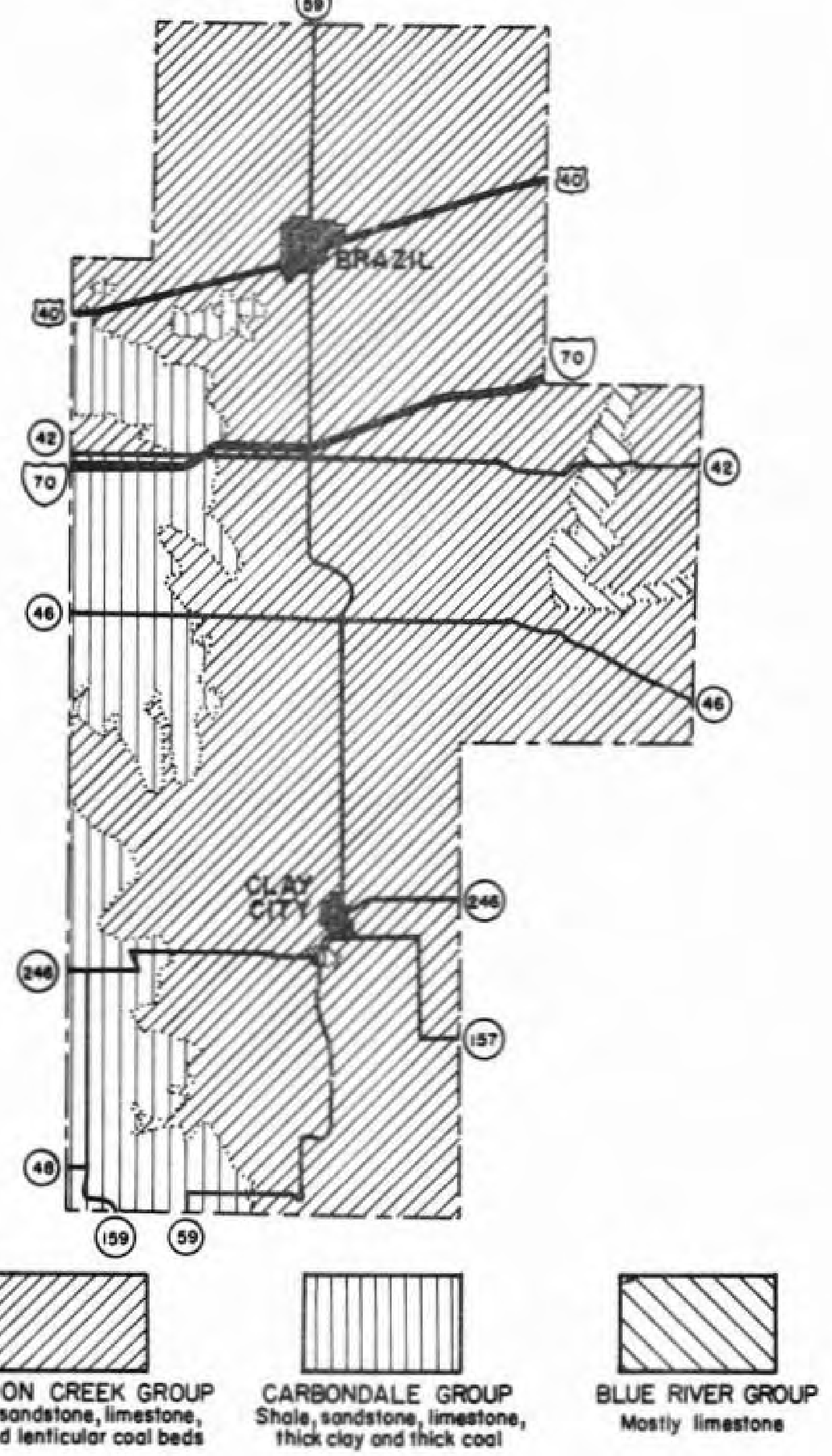

FIG. 6 GEOLOGIC MAP OF CLAY COUNTY, INDIANA 
A geologic section for the locality of Bowling Green shows the following profile (12).

Drift gravel and clay

$20 \mathrm{ft}$.

Shale and schistase sandstone

$15 \mathrm{ft}$.

Coal B

$1 \mathrm{ft}$.

Fine potter's clay

$3 \mathrm{ft} .6 \mathrm{in}$.

Blusih-black argillaceous shale and rash coal 7 to $8 \mathrm{ft}$.

Cool A ("block coal")

$1 \mathrm{ft} .3 \mathrm{in}$.

Fine clay with stigmaria

? ft.

Arenaceous shale

$30 \mathrm{ft}$.

Subcarboniferous 1 imestone

$10 \mathrm{ft}$.

Low water of Jordan Creek

$0 \mathrm{ft}$.

$88 \mathrm{ft} .9 \mathrm{in}$.

The general section of the coal measures at the vicinity of Brazil taken at Sec. 30 T13N R6W shows the following profiles (12).

Soil and drift

Iossiliferous limestone

Blueish soapstone

Coal, K (upper "block")

Gray shale
$20 \mathrm{ft} .0 \mathrm{in}$.

$11 \mathrm{ft} .0 \mathrm{in}$.

$6 \mathrm{ft}, 0 \mathrm{in}$.

$1 \mathrm{ft} .6 \mathrm{in.}$

$16 \mathrm{ft}, 0$ in.

Thin bedded, 1 ight-colored sandstone, containing reddish bands colored with protoxide of iron $18 \mathrm{ft} .0 \mathrm{in}$.

Stiff blueish argillaceous shale $1 \mathrm{ft}, 4$ in. (This shale varies in thickness from 0 to $8 \mathrm{ft}$. )

Coal I, main "block"

Good fire clay for pottery

liard siliceous clay mixed with iron balls
$3 \mathrm{ft} .10 \mathrm{in}$.

$1 \mathrm{ft} .6 \mathrm{in.}$

$6 \mathrm{ft} .0 \mathrm{in}$. 
llard blueish shale

Soft sandstone with layers of yellowish clay

Coal, F

Fire clay

$\Lambda$ rgillaceous and siliceous shale

Gray shale with iron balls
$6 \mathrm{ft} .0 \mathrm{in}$.

$20 \mathrm{ft} .0 \mathrm{in}$.

$0 \mathrm{ft} .3 \mathrm{in}$.

?

$60 \mathrm{ft} .3 \mathrm{in.}$

$6 \mathrm{ft} .0 \mathrm{in.}$

$177 \mathrm{ft} .8 \mathrm{in}$.

\section{LAND FORM AND ENGINEERING SOIL AREAS}

The engineering soils in Clay County are derived mainly from unconsolidated materials. The unconsolidated materials include glacial deposits, glacial-fluvial deposits, alluvial deposits and eolian deposits. A very limited area may be considered as a residual soil or non-soil area. However, due to the scale limitation of the attached map many narrow strips of rock outcrops along the valley wall of the major rivers and streams of the county cannot be shown. In the strip mining areas, the waste piles, as indicated on the map, should be considered as non-soil areas.

The deposits of transported materials are not homogeneous and variation should be expected. General properties and profiles of the soils for each area of different land form, are presented in this report.

\section{GLACIAL DEPOSITED MATERIALS}

Essentrally all the soils of Clay County are of glacial origin. The major portion of the county is covered by glacial deposits of Illinoian age called the Butlerville Till Member of the Jessup Formation. Wisconsinian glaciation covered these with eolian deposits of loess and windblown 
sand. Wisconsinian glaciation also produced alluvial soils, terrace soils and lacustrine soils.

Owing to the long period of weathering and erosion the end or ridge moraine of the Illinoian age is no longer visible. The entire glacial deposits are covered by windblown sands and silts with a depth varying from 10 inches up to 10 feet. The soil derived from more than six feet of sands and loess will be considered as windblown deposites and discussed separately.

1. Ground Moraine of I1linoian Age with Thin Loess Mentle

Ground moraine deposits of the Illinoian Age with a loess mantle less than six fect occupies the main part of Clay County. Narrow strips along the valley walls in the loess region may be considered under this category because the thick loess of this region are reduced in depth by erosion. However, the limitation of the map scale prevents the detail delineation of this deposit. This thin loess mantle is not considered under the heading of eolian deposit. Due to the different type of vegetation cover, the deposit is subdivided into timber and prairie soils. (A) Loess Covered fround Moraine of Illinoian Age - Timber Region

The main portion of the ground moraine deposits in Clay County belong to this category. The topography of this ground moraine varies from nearly level to slightly undulating. Gullies along the major streams are deeply incised into the upland giving the area a rugged look. Many areas are still under timber cover, especially along the steep valley walls of the streams. The well developed white fringe 
along the dark centered gullies is the typical airphoto pattern of this deposit.

The upper horizon of the solun is derived from the loess material. The thickness of the loess cover depends greatly on the topography and the distance fron the river. On steep slope where erosion is severe, the loess covering may have been renoved.

The soil profile shows that the A-horizon is a silt loan or silty clay loan (A-4 soil). Silty clay or clay (A-6 to A-7-6 soil) are encountered in the B-horizon. A leached parent material is found with a texture from a silt loam to a clay loan (A-6 soil).

Boring data along Interstate $1-70$ reveal some of the characteristics of the thin loess covered I11inoian drift deposits (sce Appendix $A$ ). The entire route of $1-70$ is located within this region. Among the 98 samples taken within the county only ten are located within the gully, valley wall and stream flood plain areas.

The top soil taken from the surface to a depth of 0.8 foot is a silty clay loam (A-4(8) soil) at station nos. 1 , $34,41,45,48,49$ and 56 . It was classified as silt loam (also $A-4(8)$ soil) at station nos, 18 and 38 . The sieve analysis shows that the anount of sand varied from 6 to 16 percent, silt between 62 and 71 percent and clay 20 to 29 percent. Samples taken from the surface or a little below the surface to a depth of two feet or more are more variable in texture. The content of clay generally increases with depth. Loam, silt loan, silty clay loan, silty clay and 
clay loam are all recorded for this layer. The samples are classified mostly as A- 6 soil by the AASHO Classification. However, A-4 and A-7-6 soil (at sites nos, 9, 24, 52 and 72) are also found. The B-horizon taken at a depth from about two to four feet is recognized essentially as silty clay or A-6 to A-7-6 soils. Generally the sand content is less that 10 percent, the amount of silt ranges from 50 to 60 percent and the clay portion is around 30 percent. Occasionally silt loam and clay loam (A-4 soil) may be encountered (at site nos. 27 and 20 respectively). The C-horizon taken from four to six feet below the ground surface is generally classified as clay loam to clay (A-4 to A-6 soil). However, silty clay to clay (A-7-6 soil) are found at site nos. $47,49,53$, 81,85 and 95 . The Illinoian glacial till taken from a depth between six to ten feet or more is classified as clay loam and clay in general (A-6 to $A-4$ soil). The percentage of sand increases while the amount of silt decrease from the layer above. A small amount of gravel also is present in this layer. Exceptional cases are: a sandy clay loam (A-4) found at a depth between eight to ten feet at site no. 65 and a clay soil (A-7-6) encountered at site no. 69 at the same depth.

(B) Loess Covered Ground Moraine of Illinoian Age - Prairic Region

About three square miles of land scattered between Cory and Prairie City in the west - central part of Clay County is recognized as loess covered ground moraine of Illinoian age developed under the influence of prairie vegetation. The largest area lies northeast of Cory. 
Nearly level topography prevails in these areas. Surface drainage is poorly developed in most of the area. However, tile drains are used extensively in this area to facilate drainage. The darker and more uniform photo tonality of this deposit makes the delineation of the boundary fairly easy.

The soil profile is characterized by a slightly organic silt loan to an organic silty clay loan $(A-4$ soil with organic matter) top soil, a silt loam or silty clay loam $(A-4$ to $A-6)$ subsurface soil and a silty clay to clay $(A-7-6)$ subsoil. These layers are developed in the loess material with a thickness of about three feet. The material underneath varies from a silty clay loam to clay containing partially weathered rocks. The unweathered calcareous Illinoian till with a texture of clay loam to clay (A-6 soil) is found eight to twelve feet below the surface. 2. Thin Illinoian Drift Over Sandstone-Shale

The thin Illinoian drift over sandstone-shale areas are confined in the southeastern corner of the central section of Clay County. The largest area lies north of Six Mile Creek. Others are scattered along Jordan Creek east of Bowling Green. At places along the streans the sandstone-shale may be exposed and considered as non-soil area. Because the width of the exposed rock areas is very narrow and cannot be shown on the accompanied map, the non-soil areas are included within this category.

The deposits are generally situated between the I1linoian drift upland on one side and the stream botton on the other. 
The topography in the area is more rolling and dissected than that of the Illinoian till plain. Along Jordan Creek the deposit is confined to the valley wall. The land is nostly used for timher hecause of the stecp slope.

The soil of this area is developed from a blanket of loess(1ess than 48 inches in thickness) underlain by weathered 111 inoian drift and then sandstone-shale. The upper soil profilc is essentially the same as the soil of the Loess Covered ground noraine of 111 inoian age - timber region. The silt loan or silty clay loam top soil may be absent on steep slope. The B-horizon consists of silty clay to clay soil. Clay loam and clayey soil form the C-horizon overlying the interbedded sandstone-shale.

FLUVIAL DEPOSITED MATERIALS

Nearly one third of Clay County is covered by fluvial deposited materials. Four different land forms created by the action of water, namely, outwash plain, terrace, lacustrine plain and alluvial plain are discussed as follows: 1. Outwash Plains

Less than two square miles of land in Clay County are considered as outwash plain deposits. These outwash deposits during the lllinoian glacial period are confined to the northwestern corner of the county and the northeastern corner of the central portion of the county. The deposits are relatively small and widely scattered. They nay be considered as remments of a larger plain. Only the area at Poland has a nearly level surface. The deposits also occur on knolls, and as ridges slightly above the surrounding till 
plain. No surface drainage has been developed in this well drained deposits.

Soil developed in this area are derived from a loess blanket with a thickness from less than 18 inches to about 42 inches and the underlying sandy outwash material. The outwash deposits varies in depth and the composition is mainly sands with a small amount of gravels.

The soil profile consists of a surface material that varies from a sandy loam to a silt loam $(A-4$ soil). The subsurface soils are somewhat more clayey in texture, ranging from a loam to silty clay (A-6 soil). The strat. ified waterlaid sands and gravels (A-2 to A-4 soil) are found from about threc to six fect below the surface. The depth of leaching of this soil is about 15 feet. 2. Terraces

Only a few small areas along Eel River, south west of Bowling Green and one strip at the tip of a tributary of Cory's Creek at the northeastern corner of Clay county are classified as terrace deposits. These terrace deposits werc formed under slackwater condition. Therefore they may be considered as slackwater terraces.

The slackwater terraces are extremely flat and are slightly higher than the adjacent flood plain (about 10 feet). Infiltration basins are current scars are missing in these terraces. Surface drainage is not very we11 developed. Surface channels are widely spaced. 
The soil of the slackwater terraces are developed from stratified silt, clay and fine sand. The soil profile of these terraces consists of a silt loam or silty clay loam (A-4) top soil and a plastic silty clay loam or silty clay (A-6) subsoil. The lower portion of the subsoil contains less clay than the subsurface soil. The stratified parent material varies greatly in texture from place to place. The strata may contain a silty clay loam, loam, silt and some fine sand (A-4,A-6 or A-7 soil). 3. Lacustrine Plains

There are about 15 square miles of lacustrine plains in C1ay County. Two large areas are located north of the Eel River. One lies southeast of Saline City and the other is situated along the Big Slough Creek and Splunge Creek. Other small lucustrine plains are scattered west of Eel River on the southwestern corner of the county and along Six Mile Creek, Jordan Creek and the eastern portion of the central part of Clay County.

The topography of the lacustrine plain is a nearly level plain broken only by widely spaced drainage channels. Occasionally white fringes around the gullies reveal the presence of silt veneer over the fine-textured lacustrine deposits. The topographic break between the glacial upland and the adjacent flood plain is pronounced in places but obscure in others. The boundaries between flood plains and lacustrine plains are very difficult to delineate in the southwestern quarter of the county. In addition, the lacustrine plain deposits in the southwestern corner of 
the county is rather thin. The deposit was washed in from the adjacent upland. In fact, it may be called a colluvial deposit in places.

Soils of these lacustrine plains are developed from a shallow b1anket of loess material, ranging from 6 to 50 inches in thickness, which is underlain by stratified lacustrine deposits. The top soil of this deposit varies from a silt loam to silt clay $(A-4$ to $A-6$ soil). In the slightly depressed areas where the soils are very dark in color, the top soils contain some organic matter. The subsoils are a very plastic silty clay or clay (A-7-6 soil). $\wedge$ clay loam laycr may be encountered before reaching the stratified parent material. The texture of the stratified lacustrine deposit varies from place to place. Clay and silt $(\Lambda-6$ or $\Lambda-7$ soil) with occasional thin 1ayers of fine sand are predominate. However, Clay Loam, silty clay and fine sandy loam may be encountered. The reader may refer to the test data for sites nos. 14,16 and 21 in Owen County (5).

4. Alluvial Plains

Clay County has a relatively large amount of alluvial plains or flood plains along its rivers and streams. The extent of mapping of these plains was determined by the scalc of the engineering soils map.

The largest alluvial plain occurs along the Eel River especially in the southern third of the county. The width of the flood plain is about two miles along the course of the river. It increases to over four miles at the 
confluence with Splunge Creck.

Most of the alluvial plains have flat to nearly level surfaces. Natural levees may be found along a portion of the larger streams. Special features such as point bars, current markings, meandering stream channels, oxbows and abandoned channels are plentiful along Ee1 River and its major tributaries in Clay County.

The texture of the alluvial deposits varies greatly both laterally and vertically from one place to the other. The texture of the deposit depends mainly on the nature of the drainage basin and its form of deposition. The flood plain in Clay county may be subdivided into three divisions namely; sandy textured, silty textured and highly organic topsoil.

\section{(A) Sandy-Textured Alluvial Plain Deposits}

The sandy-textured alluvial plains are mainly confined in the Ee1 River Valley (not delineated on the soil map). The deposit is about one mile in width located along the river channel. Current scars, point bars and natural levees are numerous in this region. The deposit is generally lighter in tone than the adjacent silty-textured deposit. Sandy textured deposit may be found near the channels of the large streams and some gully bottoms.

Surface soils are most often sandy loam and silt loam (A-4 soil). The subsurface soil is slightly more clayey in texture (A-4 or A-6 soi 1$)$. The parent material is a stratified sandy loam, silt loam and sand and small amount of gravel may be found two to three feet below the surface. 
Boring data of I-70 (at sites nos. 75 and 76) taken four to six fect from the surface is classified as sand and sandy loam $(\Lambda-2-4)$ soil.

(15) Silty-Textured Alluvial Plains

The majority of the alluvial plains in Clay County are of a slity texture. In the tributaries of Eel River the soils are derived from the material of the surrounding loess covered uplands. Along Eel River the deposits lie in the slackwater region. The topography of this deposit is nearly level. Water scars and other features are less common and less pronounced than in the sandy texture region.

The surfacc soil is generally a silty clay loam $(\Lambda-4$ or $\Lambda-6$ soil) and the subsoil is silty clay (A-6 to $\Lambda-7)$ in texture. Stratified slity clay loam and silt loam (A-4 to A-6) is two to four feet below the surface. The sand content in the deposits increases toward the stream. At place it may become a sandy-texture as illustrated in the boring data at site no. 75 and 76 . At the bottom of the gully and small stream where the material is deposited under swift waters, a more coarser sediment may occur. Boring data along $1-70$ at site nos. $8,16,44$ and 79 verified this condition. Most samples taken from the surface to a depth of 2.5 feet are a sandy loam A-4 soil (about $53 \%$ of sand 24 to $32 \%$ of silt and 15 to $18 \%$ of clay). At test site no. 79, the sample is taken between 0 and 5 feet, and is classified as a 10 am or A-4 soil (3\% grave1, 41 ? sand, $38 \%$ silt and $18 \%$ clay). 
(C) Ilighly Organic Topsoil Alluvial Plain

Two sizable areas in the southern part of Clay County are identified as highly organic topsoil alluvial plain. Some oxbows and abandoned channels may be included in this category.

These 1 and forms have an extrenely flat and smooth topography. It is slightly lower than the adjacent flood plain or forms a depression. Uniform dark soil tone occurs in these areas due to high moisture and dark colored soils.

The surface soil contains a considerable anount of organic matter. It varies from an organic silty clay to organic clay $(A-6$ or $A-7$ soil). The subsurface soils are more clayey $(\Lambda-7$ soil) in texute but less organic. The parent material is a stratified silty clay loam and silt loan $(\Lambda-6$ soil).

\section{EOLIAN DEPOSITED MATERIALS}

There are extensive eolian (wind) deposits in C1ay County. The eolian deposits are subdivided into two groups: sandy deposits and loess deposits.

1. Windblown Sand Deposits

Considerable amount of 1 and (about 13 square miles) in Clay County are covered by a thick mentle of windblown sand. Owing to the northwestern prevailing wind, the sand deposits are almost entirely confined to the east side of Eel River. According to their different depositional forms, the windblown sands are subdivided into four groups nanely: sand 
dune deposits, sandy plain deposits, windblown sand on terrace and windblown sand on lacustrine plain. (A) Sand Dunes

Numerous sand dunes are recognized in Clay County. Most of then are scattered on the sandy belt of the county hordering the eastern edge of the Lel River botton. The dunes are concentrated in the area northwest of Clay City. Three small isolated knolls occur on the westside of Eel River (two about $31 / 4$ miles of Bowling Green and another $11 / 4$ miles north fron the sane city).

The sand dunes in Clay County vary in shape from a simple mound to a series of ridges. The relief of the dunes also varies from a few feet to more than 15 feet. The prominent dunes are delineated individually and marked with a sand dune symbol on the attached engineering soils map.

Although the materials of the sand dunes are predominantly fine uniform windblown sands, considerable amount of silt and clay particles were also blown and mixed with the fine sands. The surface soils are usually fine sandy loam or fine sand (A-4 soil). Sandy clay loam or clayey sand $(A-4$ soil) are the soil texture in the B-horizon. Sand banded with loamy fine sand usually occurs before the fine sand (A-3 or A-4 soil) strata is reached. (B) Windblown Sandy Plain Deposits

The sandy plain deposits occur nainly on the southeastern part of Clay County east of Eel River. It is a continuous strip with a maximun width of about two miles near Clay City. 
An isolated sandy plain lies on the western edge of liel River located about two miles north of Bowling Greca.

These sandy plain deposits have an undulating to ncarly level topography. Surface drainage ways are not wel1 developed in this region except along the edge of the bluff of Le1 River and in the vicinity of C1ay City where the deposit is thin.

A great deal of silt and clay have been mixed in the sand deposit. The surface soils vary from sand to loam (A-4 soil). The B-horizon is quite variable in texture. Sandy clay loam to sandy clay $(A-4$ soil) is found in the high position to a clay loam or clay (A-6 soil) in the depression. The parent material is a fine sand (A-2-4 or A-4 soil).

(C) Windblown Sand on Terrace

Three small areas bordering Lel River just south of Bowling Green arc considered as windblown sand deposits on terrace.

The deposits have a humocky topography. The deposit obliterates the characteristics of the underlying slackwater terrace. At places the sand blanket is thin and the characteristics of the slackwater terrace become evidence.

The surface soil varies from sand to silty clay loam (A-4 soil). The B-horizon contains more clayey material and the texture ranges from a sandy clay loam to clay (A-4 soil). The lower portion is a mixture of windblown and water deposited sand and silt $(\Lambda-4$ soil). In the thin sand blanket area the stratified silty clay loam, loam and fine 
sand of the slackwater deposit nay be encountered about four feet fron the surface.

(1)) Windblown Sand on Lacustrine Plain

A strip of land bordering the Eel River bottom from a nile north of Rowling Green to a point about $1 / 2$ niles northwest of Poland is recognized as windblown sand on lacustrine plain.

The deposits generally have an undulating topography. The characteristic of the lacustrine plain is obliterated by the sand blanket. The surface drainage is well developed along the bluff of Eel River.

The soil profile is essentially the same as the windblown sand on terrace except that the underlying lacustrinc material, stratified clay and silt $(\Lambda-6$ soil) is finer than the slackwater terrace deposits.

2. Loess Plain Deposits

An arca of the northwestern corner of Clay County is considered as a loess plain deposit. The loess is over six feet in depth underlain by lllinoian drift and followed by the sand stone-shale of the coal measure.

The loess area in Indiana has been mapped previously by Noultrop on a regional basis (15). Some minor changes or refinements have been made for this county engincering soils map.

The topography of the loess plain is gently undulating in Clay County. Surface drainage ways are well developed along the major streans. However, the typical frond - like drainage pattern in deep loess plain is absent. In the 
flat area a phanton drainage pattern verified the presents of the we11 drained loess deposit on the less pervious Illinoian drift soil. The reader should be aware that on the steep slopes of the valley walls a thinner deposit or a lack of loess covering may occur because of erosion.

The soil profile of the loess deposit has a silt loam or silty clay loam $\Lambda$-horizon $(A-4$ or $A-6$ soil). The $B-$ horizon is a more plastic silty clay to clay soil (A-7-6 soil). The C-horizon ranges from silt loam to silty clay loam $(A-6$ soi1).

\section{MISCELLANLOUS}

Strip Mines

Numerous coal strip mines are located in Clay County. Some of them are still operating others are abandoned. Both the pit and the spoil material are outlined on the attached engineering soils map. The spoil was frequently dumped in elongated ridges and consists of a heterogeneous mixture of soil materials, sandstone boulders and slabs, shale slabs and some coal. Some of the older spoil has been reforested. Many pits contain water forming lakes as indicated on the map.

The boundary of the strip mine is based on the 1939 airphoto and the available topographic maps and high attitude strip airphoto taken at 1970. Some of the stripping has been subsequently widened and some new sites have also been opened. Field investigation of this area is required. 


\section{Underground Mines}

A number of underground mine operations were sighted on the 1939 airphotos. Most of them are located in the northern part of the county. The underground mines are indicated also on the attached engineering soils map. Kaste pile and occasional basins developed on the surrounding surface duc to the collapse of the underground chambers are the special features of this operation. The engineers should investigate the location of the underground mining area before the design of important structures. Shale Mines

Several pits are recognized as shale pits or quarries in Clay County. They are located both north and south of Brazil. A large factory with many kilns can be observed near the shale pits from the 1939 airphotos. Some of the abandoned pits hecame lakes and ponds. The shale pits are indicated with appropreate symbols on the attached soil map. Some of the pits have been subsequently widened, therefore, some representative areas on the map may be too sma11.

Sandstone Quarries

One sandstonc quarry is revealed in the 1939 airphoto on the sandy plain about one mile southwest of Clay City. This verify the statement of thin sandy plain at the vicinity of Clay City as nentioned previously. This quarry has been a strip mine in recent years. Sandstone quarries were reported in Sec. $29, T 9 N, R 7 W$ and in Sec. 20 of the sanc township by Scovell (16). However, nothing of the kind 
is noticable in the airphoto. A pond in Sec. 29 might be the result of the abandoned quarry.

Grave1 pits

Very little gravel deposits are available economically in clay County. A large gravel pit is located in SE $1 / 4$ Sec. $12 \mathrm{~T} 13 \mathrm{~N}, \mathrm{R} 7 \mathrm{~W}$. It is now abandoned and has become a pond. It was reported by Scovell (16) that the gravel deposit had an area of 100 acrea with a depth from 10 to 50 feet in thickness and under three to five feet of clayey soil. Other small ones are located at the stream bottom at section 10 and $11, T 13 \mathrm{~N}, \mathrm{ROW} . \mathrm{A} 11$ of them are abandoned and have become man-made ponds. Some gravel deposits are found along Eel River north of Bowling Green. However, only one is recognized (about five mile north of Bowling (ireen) in the 1939 airphoto. 
1. Frost, R. E. et al, "Manual on the Airphoto Interpretation of Soils and Rocks for Fingincering Purposes", Joint llighway Research Project, Purdue University, Lafayette, Indiana, Narch 1953.

2. Belcher, D. J., Gregg, L. E. and Woods, K. B., "The Formation Distribution and Fnginecring Characteristics of Soils", Engineering Bulletin No. 87, Engineering Experiment Station, Purdue University, Lafayette, Indiana, 1943.

3. Jones, G. B., Maniford, C. B., Bushne11, T. M. and Oyler, R. P., "Soil Survey of Clay County, Indiana", Bureau of Soils, U. S. Department of Agriculture in cooperation with the Purdue University Agricultural Experinent Station, Government Printing office, Washington, D. C., 1927.

4. Ych, P. T., "Engincering Soils Map of Vigo County, Indiana", Joint llighway Research Project, Purdue University, Lafayette, Indiana, August 1971 .

5. Yeh, P. T., "Airphoto Interpretation of Engineering Soils of Owen County, Indiana", Joint IIighway Research Project, Purdue University, Lafayette, Indiana, August 1966.

6. "United State Census of Agriculture 1964", Vol. 1 Part 11, Burcau of Census, United States Department of Commerce, Government Printing office, Washington, D. C., 1965.

7. "United States Census of Population 1970", Bureau of Census, United States Department of Commerce, Government Printing office, Washington, D, C., 1971.

8. "C1imatological Summary", Environmental Science Service Administration in cooperation with Purdue University Agricultural Experiment Station, M. S. Department of Commerce, November 1967.

9. Shurig, D. G., "Airphoto Interpretation of Engineering Soils of Sullivan County, Indiana", Joint Highway Rescarch Project, Purdue Iniversity, Lafayette, Indiana, Septenber 1967.

10. Logan, $\mathbb{X}$. N., "Handbook of Indiana Geology", Indiana Department of Conservation, State of Indiana, Indianapolis, Indiana, 1922.

11. Wayne, W. J., "Pleistocene Formations in Indiana", Indiana Department of Conservation, Geological Survey Bulletin No. 25, Dloomington, Indiana, January 1963.

12. Cox, E. T., "Geological Survey of Indiana", First Annual Report, Indianapolis, Indiana, 1869. 
13. Leverett, Frank, "The I1linois Glacial Lobe", Monographs of the United States Geological Survey, Vol. 38, Washington Government Printing Office, 1899.

14. B1atchley, W. S., "The Clays and Clay Industries of Indiana", 29th Annual Report, Department of Geology and Natural Resources, Indiana, Indianapolis, Indiana, 1904 .

15. Moultrop, K., "Nirphoto Boundary Delineation of Loess on Loess Like Soil in Southwestern Indiana", A MSCE thesis, Purdue University, Lafayette, Indiana, January 1953 .

16. Scove11, T. T., "The Roads and Road Material of a Portion of Western Indiana", 30th Annual Report, Department of Geology and Natura1 Resources, Indiana, Indianapolis, Indiana, 1905. 


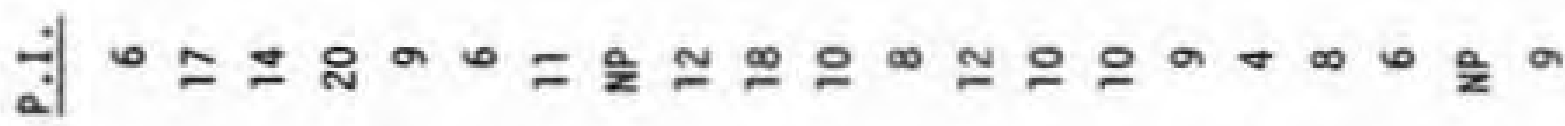
ㅂ. 범 을 곹

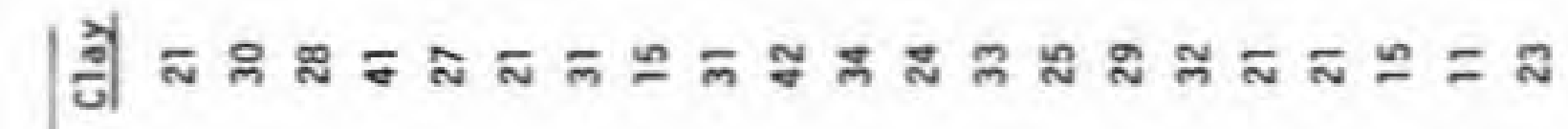
ㄴ 药 동

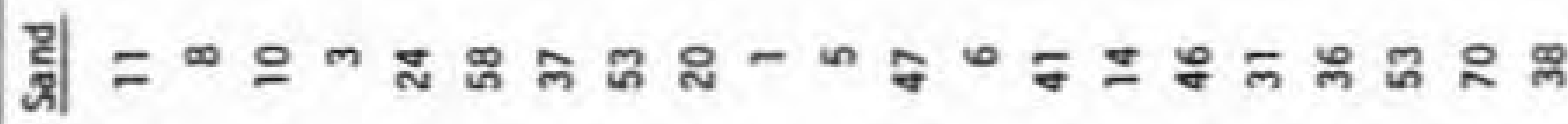

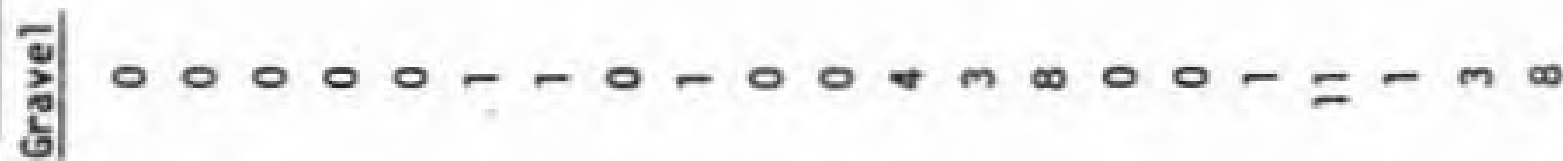

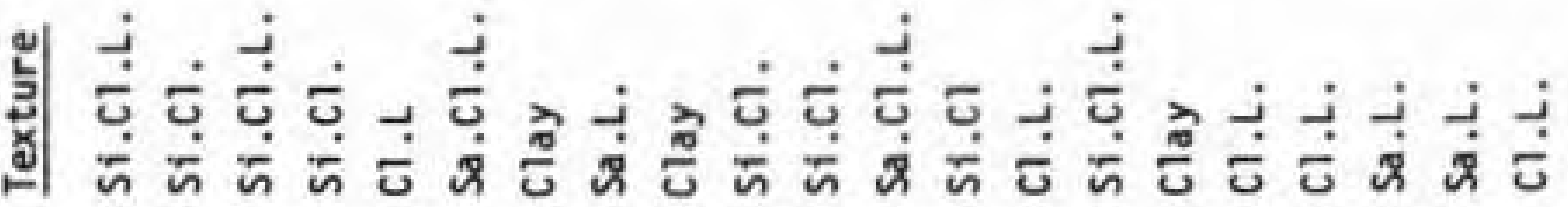
4 등

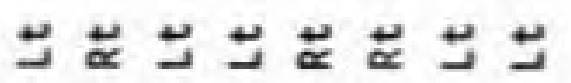

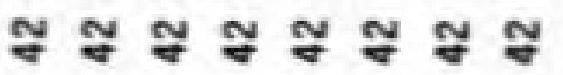

$\pm$ ₹ $\pm$

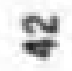

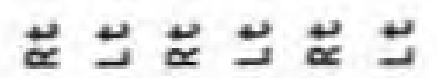

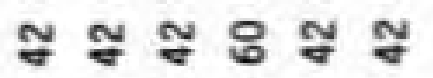

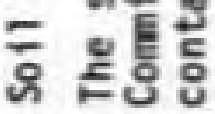

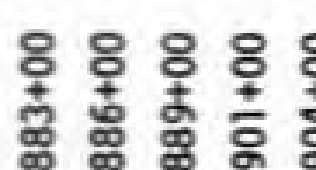

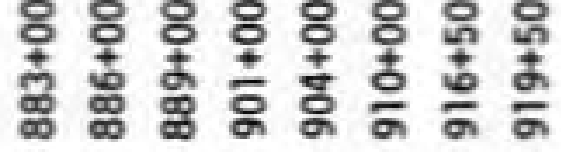

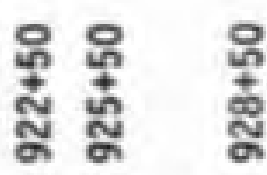

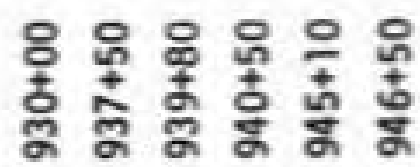

횐 


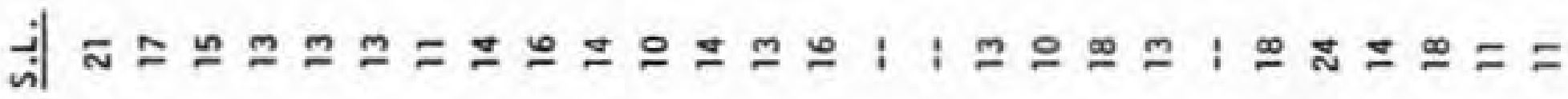

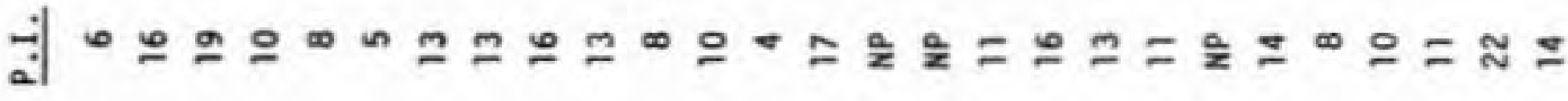

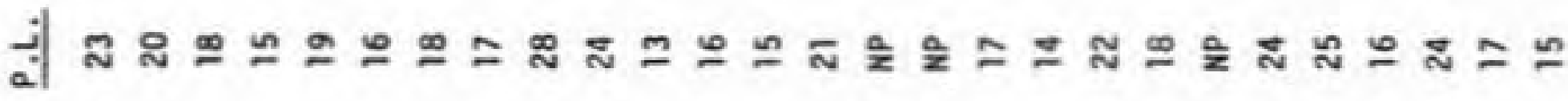

可

粼品的品ニ

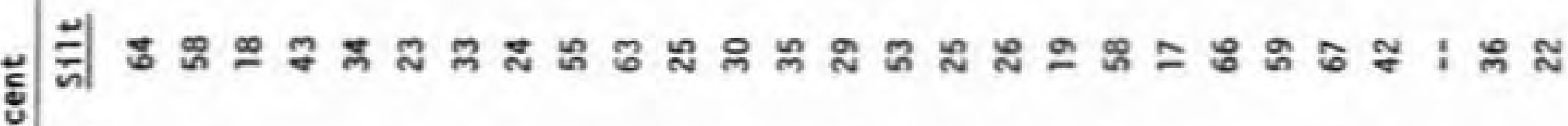

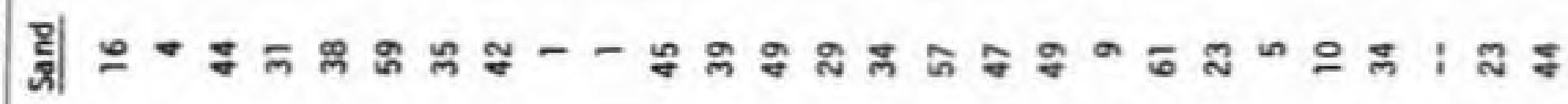
龍

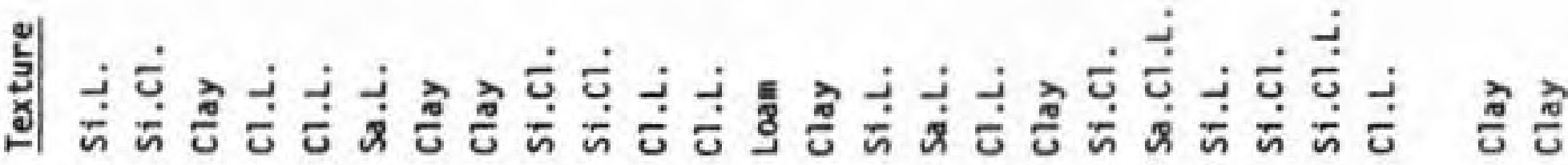

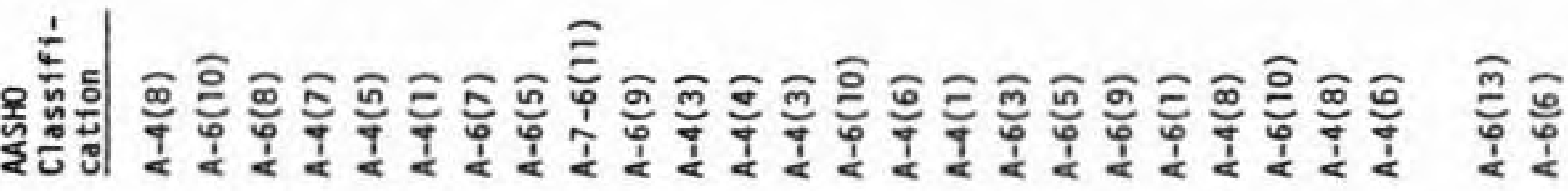

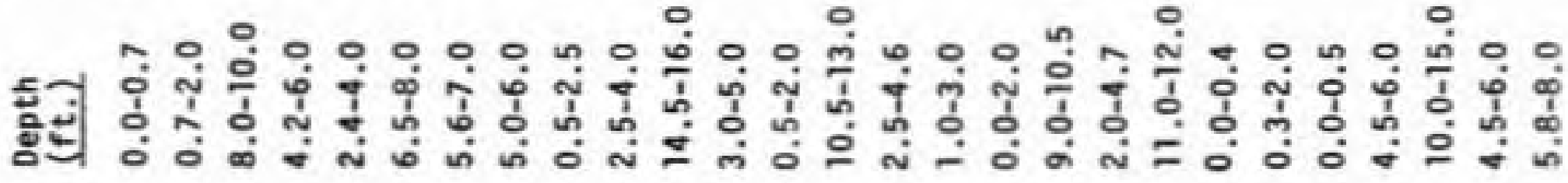

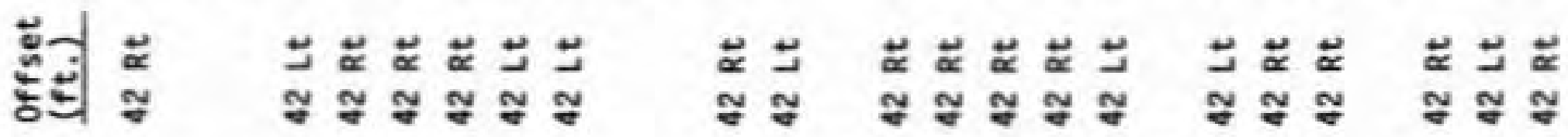

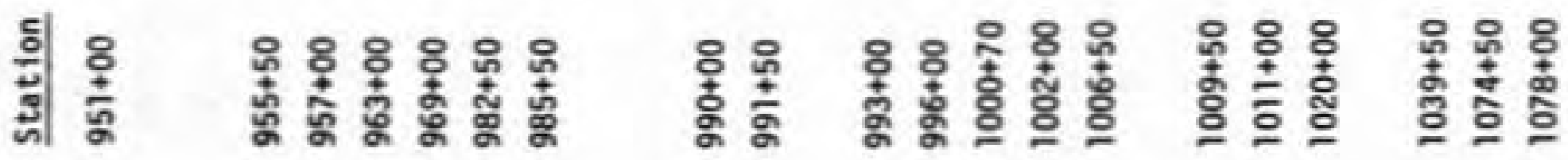

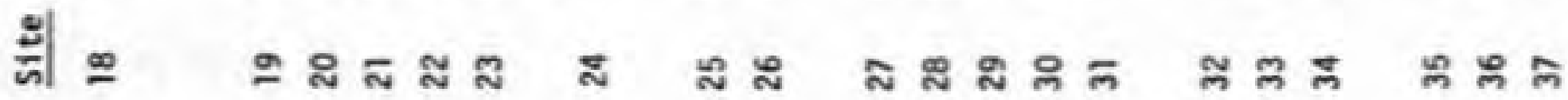




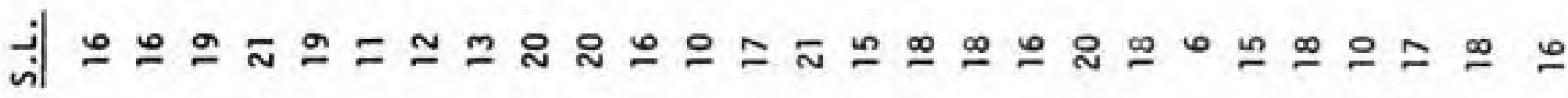

前

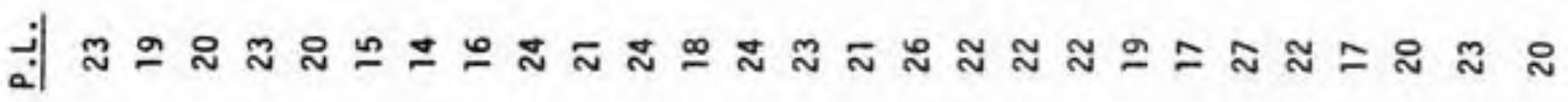

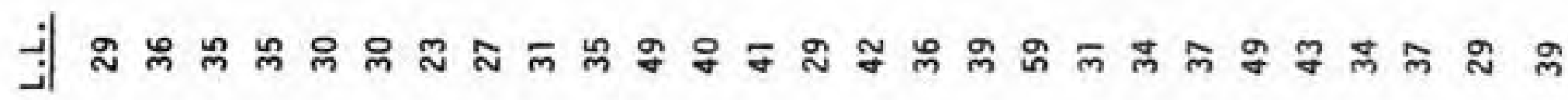

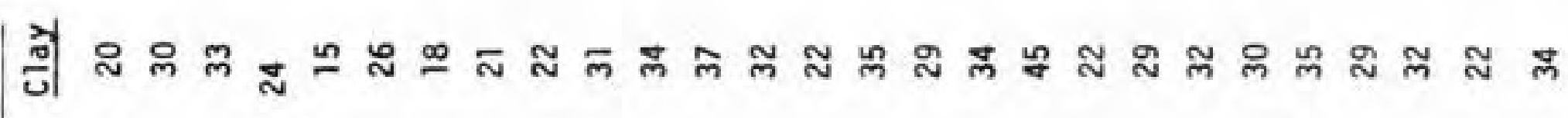

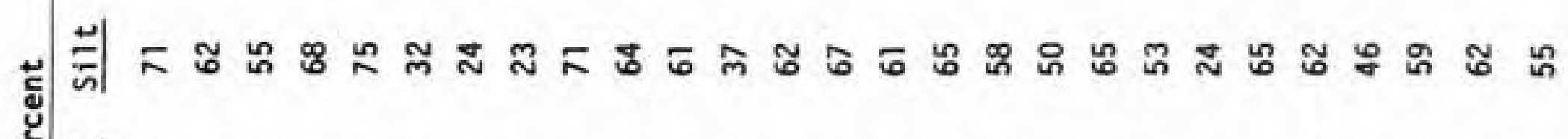

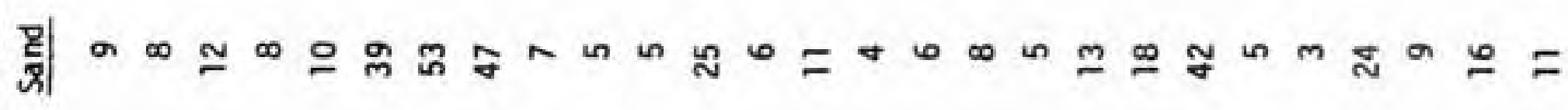

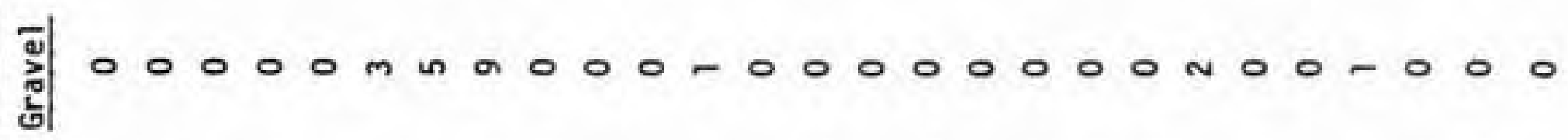

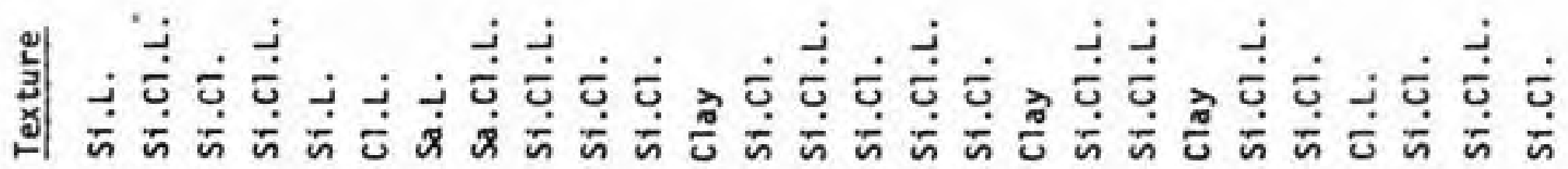

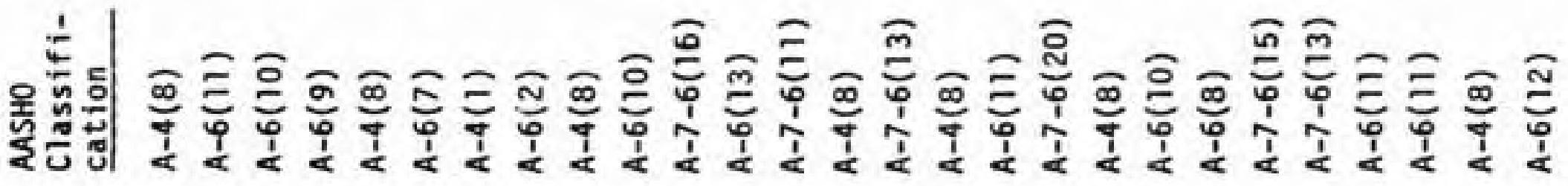

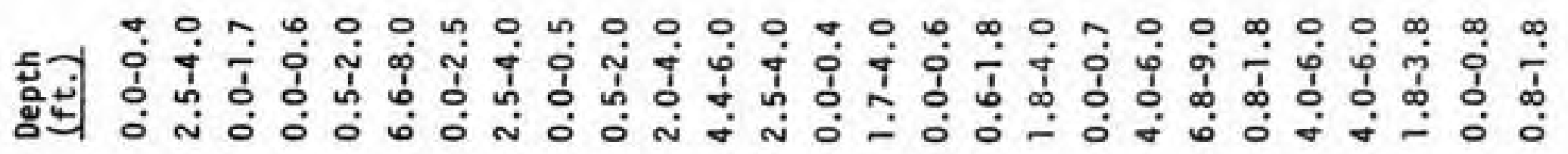

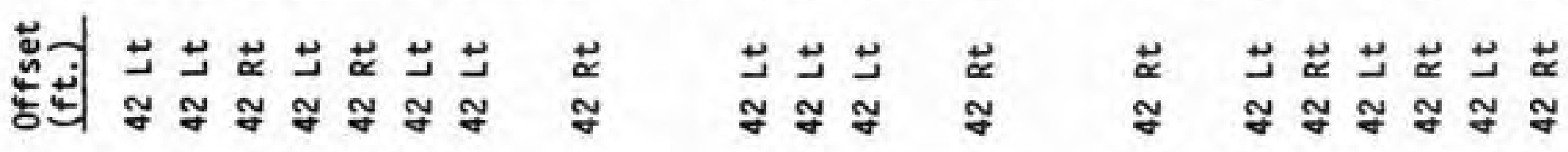

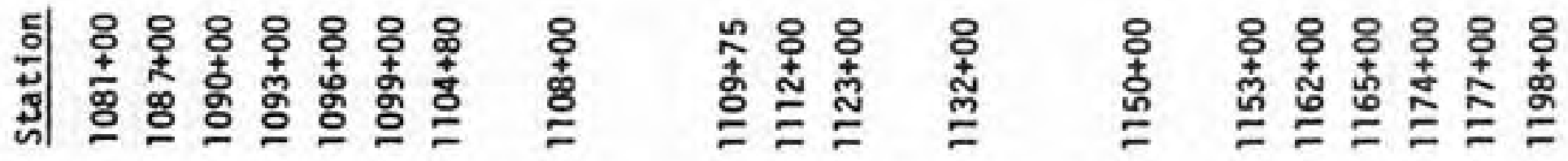

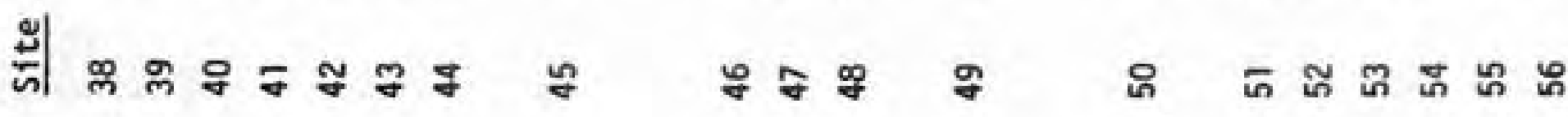




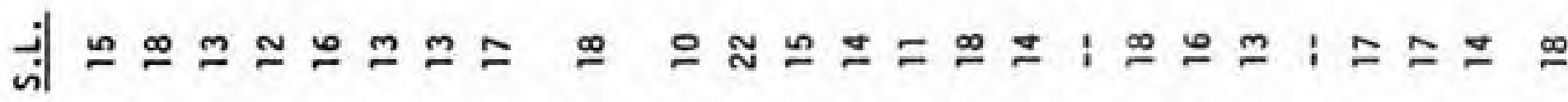

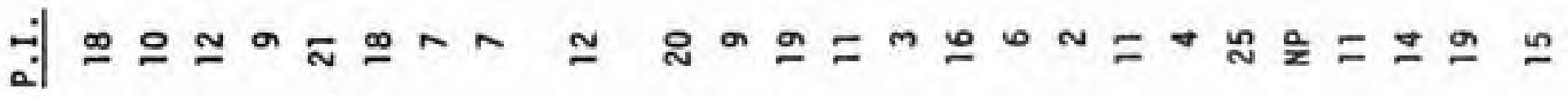

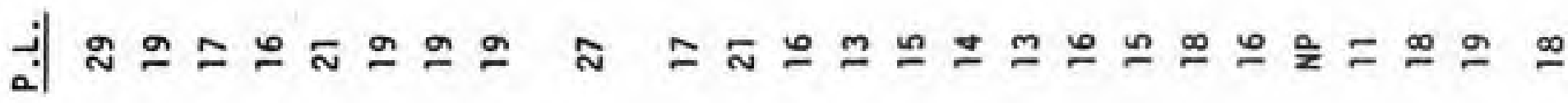

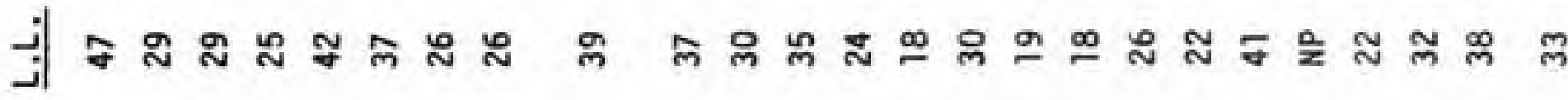
矛称品

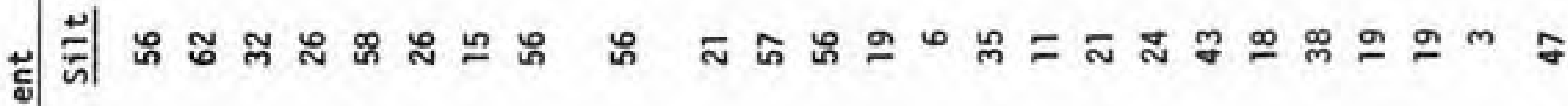
气 量 ヘ

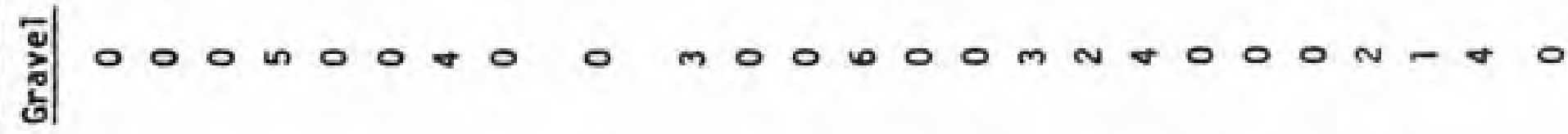

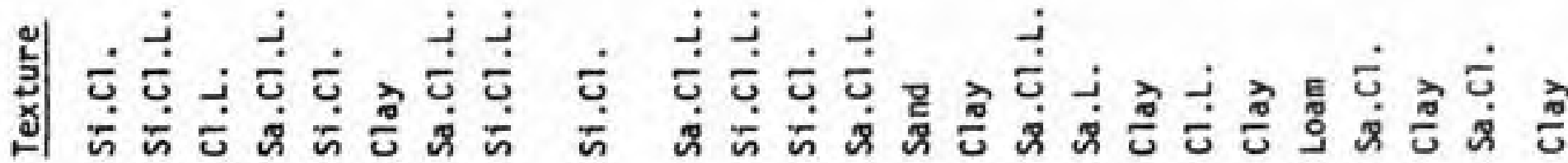

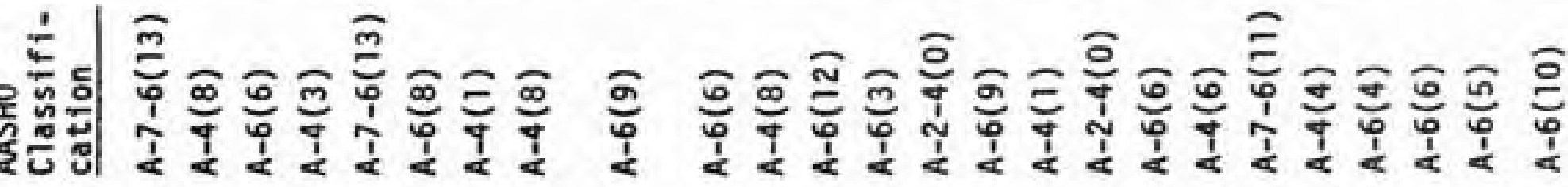

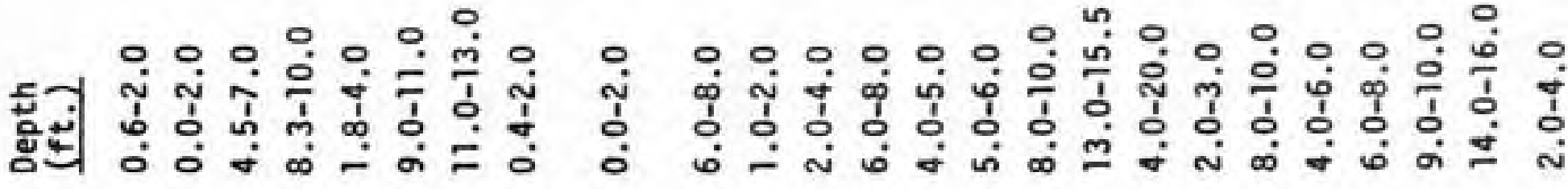

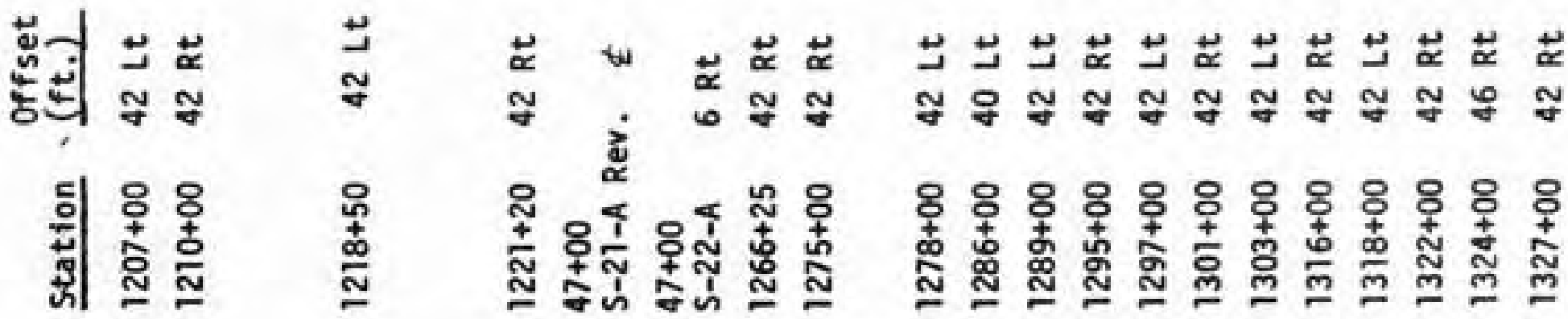




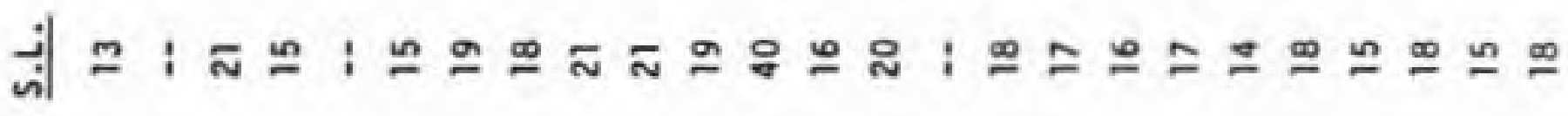

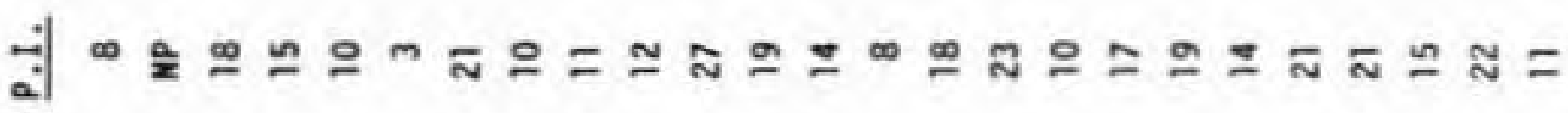
பு| 氙 |ํㅝㄴ :

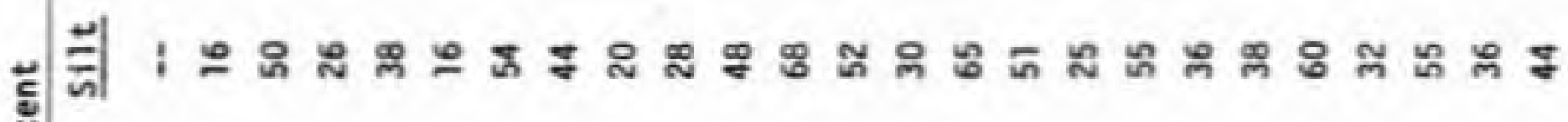

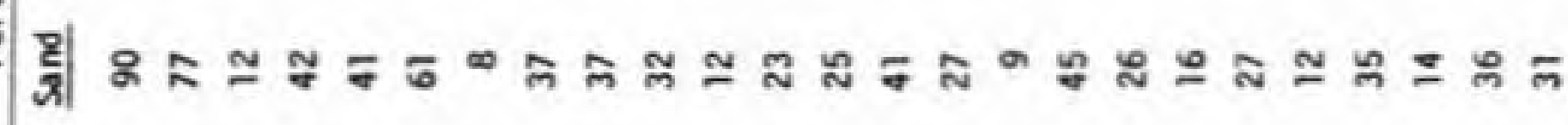

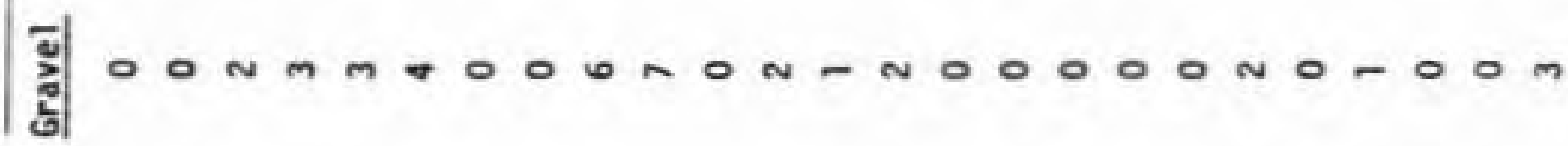

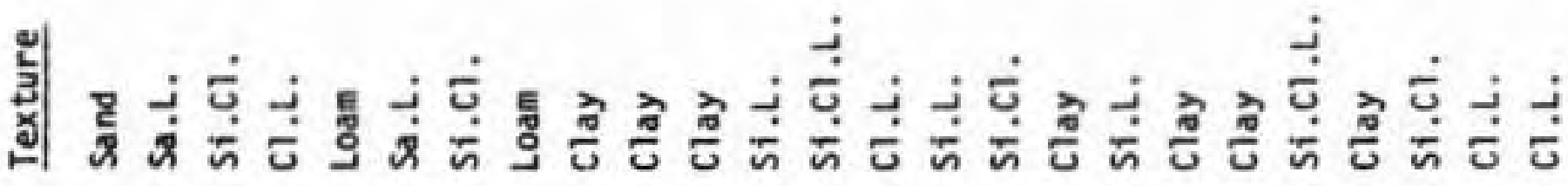

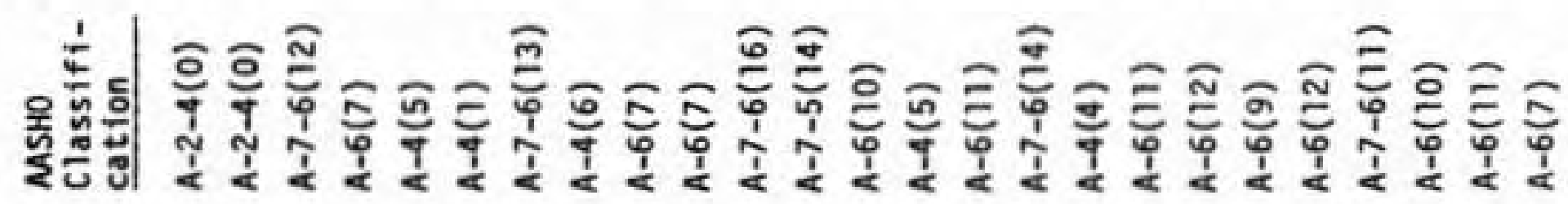

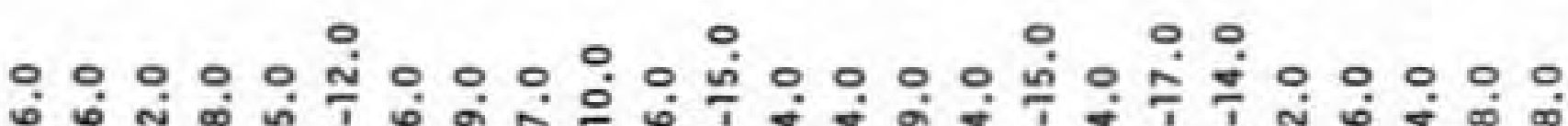

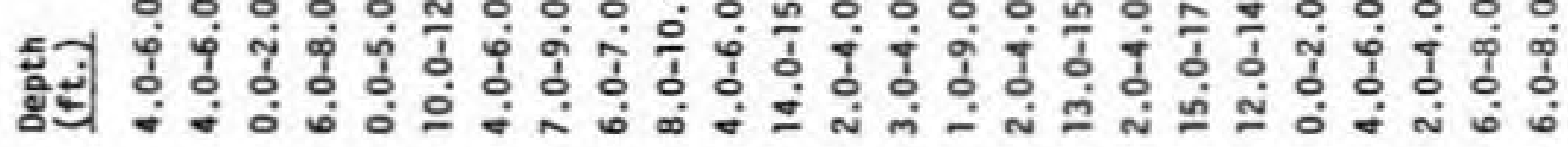

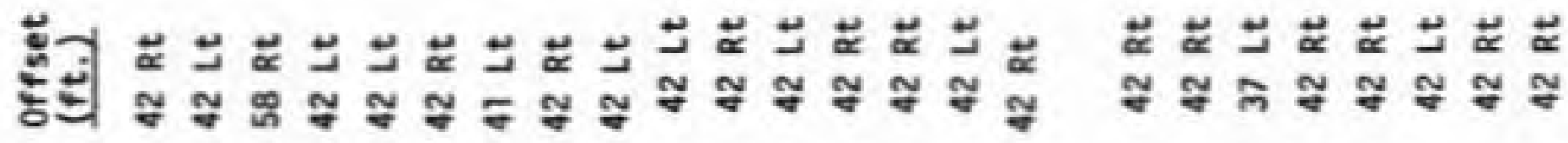

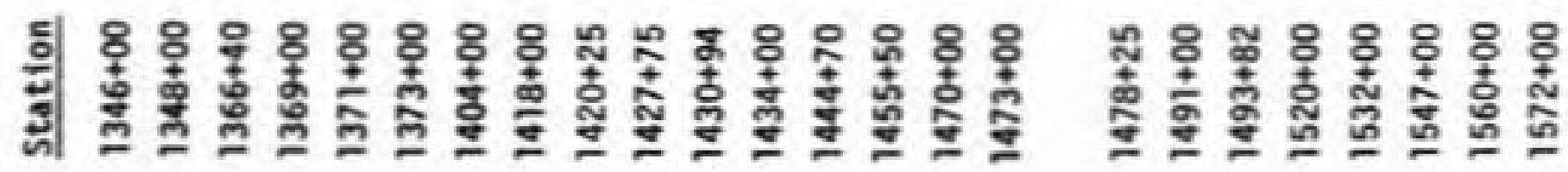

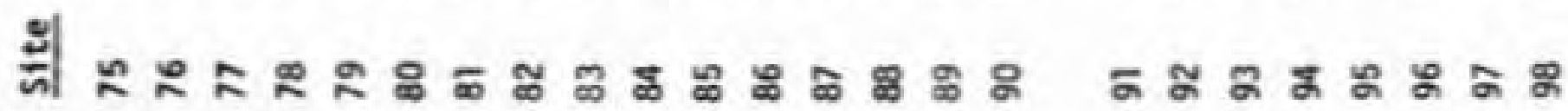




\section{APPENDEX B}

SOIL. CIASGIYILATION AND PROTIL STMBILS

\begin{tabular}{|c|c|c|c|c|c|c|}
\hline \multirow[b]{2}{*}{ Description } & \multicolumn{4}{|c|}{ Grain Size Odstribution } & \multirow[b]{2}{*}{$\begin{array}{c}\text { Plastic } \\
\text { Index }\end{array}$} & \multirow[b]{2}{*}{ Symbel 1} \\
\hline & \begin{tabular}{|c|} 
Gravel \\
3 Retasned on $\# 10$ \\
\end{tabular} & $\begin{array}{c}\text { Sand } \\
20 \rightarrow 200\end{array}$ & $\begin{array}{c}\text { S11t } \\
0.05-0.005 m m\end{array}$ & $\begin{array}{c}\text { Clay } \\
\text { Less than } 0.005 \text { ent }\end{array}$ & & \\
\hline Grave I & $85-100$ & $0-15$ & $0-10$ & $a-10$ & $N P$ & $\because \because 8$ \\
\hline Sandy Gravel & $50-85$ & $15-50$ & $a_{-10}$ & $a-10$ & $6 \mathrm{Mmx}$. & {$\left[\begin{array}{lll}\because & 0 & 0 \\
0 & 0 & 0\end{array}\right]$} \\
\hline Sand & $a-15$ & $85-100$ & $a-10$ & $0-10$ & IP & \\
\hline Gravelly Sarnd & $20-69$ & $45-85$ & $0-10$ & $a_{-10}$ & of Nax. & \\
\hline Sandy Loan & $0-19$ & $30-80$ & $0-50$ & $0-20$ & $6 \operatorname{Max}$. & \\
\hline Sandy Clay Loam & $0-19$ & $50-80$ & $a-30$ & $20-30$ & $10 \mathrm{Max}$. & 89 \\
\hline Sandy Giay & $0-19$ & $55-70$ & a-15 & $30-45$ & 11 Min. & \\
\hline Lan & $0-19$ & 30.50 & $30-50$ & $0-20$ & $10 \mathrm{Max}$. & \\
\hline S11t Lonn & $2-19$ & $0-50$ & $50-100$ & $a-20$ & $10 \mathrm{Max}$. & DADA \\
\hline Sutty Ciay Losn & $a-19$ & $0-30$ & $70-100$ & $20-30$ & $11 \mathrm{Min}$. & atide \\
\hline Silty Clay & $0-19$ & $a-15$ & $55-70$ & $30-45$ & $11 \mathrm{Mins}$ & ए17 \\
\hline Clay Loun & $0-19$ & $20-50$ & $50-80$ & $20-30$ & 11 van. & 87 \\
\hline clay & $0-19$ & $0-55$ & a-ss & $30-100$ & $11 \mathrm{Min}$. & \\
\hline \multicolumn{7}{|l|}{ Pant or Muek } \\
\hline Limantone & & & & & & $\begin{array}{ll}1 \\
1,1 \\
1,1 \\
\end{array}$ \\
\hline Sandertene & & & & & & 85 \\
\hline Shale & & & & & & \\
\hline Stony Pravents & & & & & & E \\
\hline Organie Malter & & & & & & 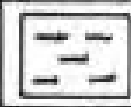 \\
\hline top soll & & & & & & \\
\hline
\end{tabular}

Classifieaston of Cravelly Soils

85\%-100\% gravel plus finer material - Grave1

$506-8,5$ gravel plua finer aterial - Clayey, silty or aundy graved

$206-69 \%$ gravel plue finer materlal = Uge fine clapsifteation and called

gravelly sand, gravelly silt or gravelly olay

ot-19s gravel plus finer material - Uoe fine classification only 


$$
\text { JHRP } 73 / 26
$$


CENERAL SOL PMOFILES

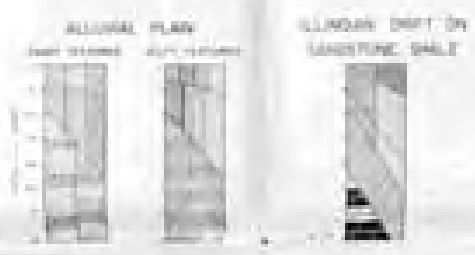

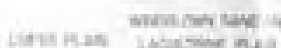

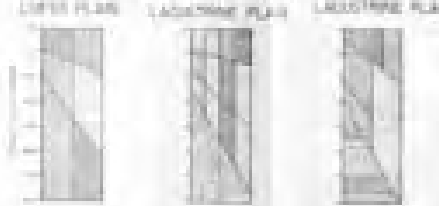

now selasu is somaris nimed
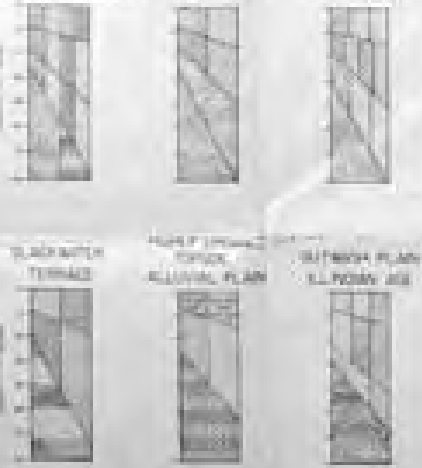
wet nail

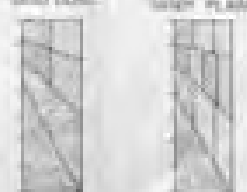



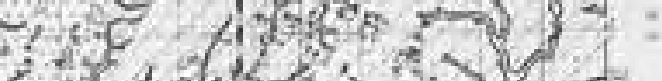

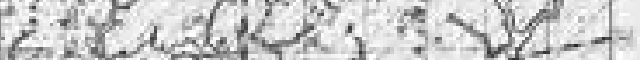

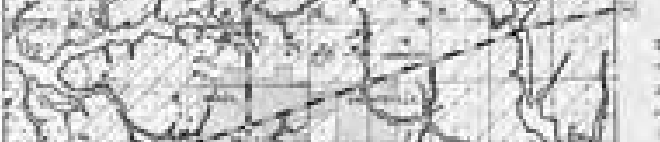

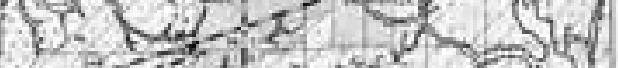

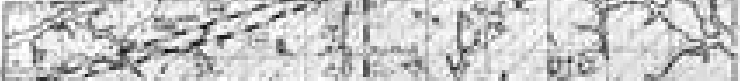

\section{(2) LEGEND}

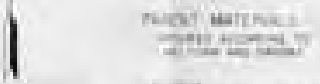

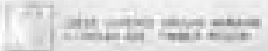

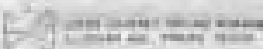

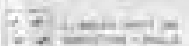

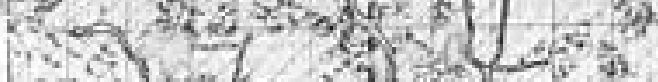

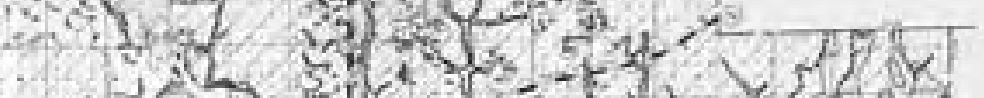
- ix 5 .

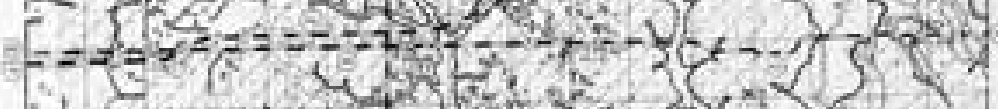

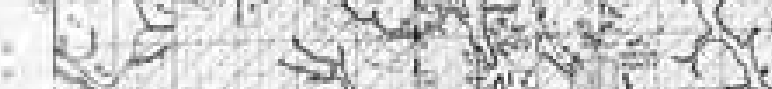

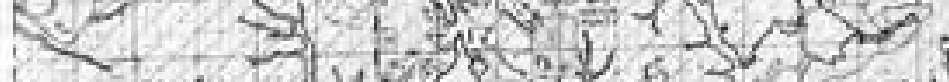

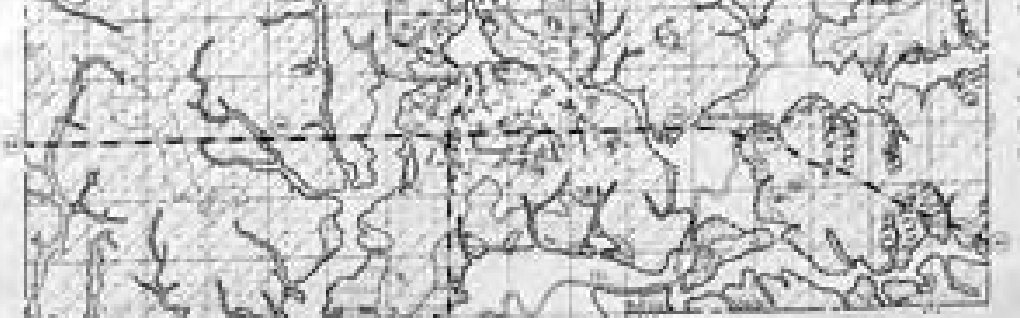

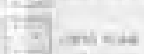

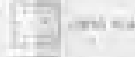<smiles>C1=CC=C1</smiles><smiles>[CH]C</smiles>

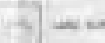
5 ion.

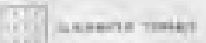

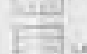
7 mits

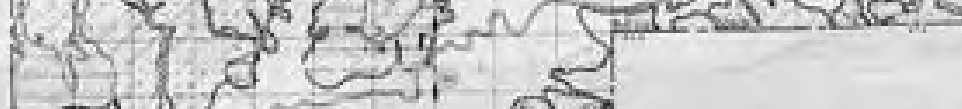

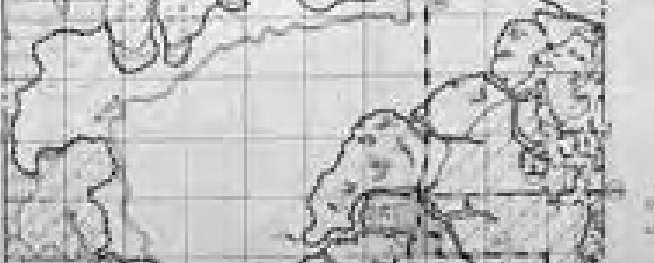

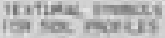

엉- 
